SANDIA REPORT SAND81-2208 • Unlimited Release

Printed November 1981

\title{
Data Reduction Facility for Digitizing and Manipulating Data from Oscilloscope Photographs (Users Guide)
}

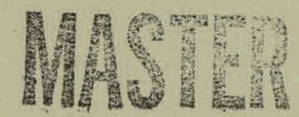

B. E. (Gene) Hammons, Douglas D. Bloomquist, Douglas W. Dugan

Prepared by

Sandia National Laboratories

Albuquerque, New Mexico 87185 and Livermore, California 94550

for the United States Department of Energy

under Contract DE-AC04-76DP00789

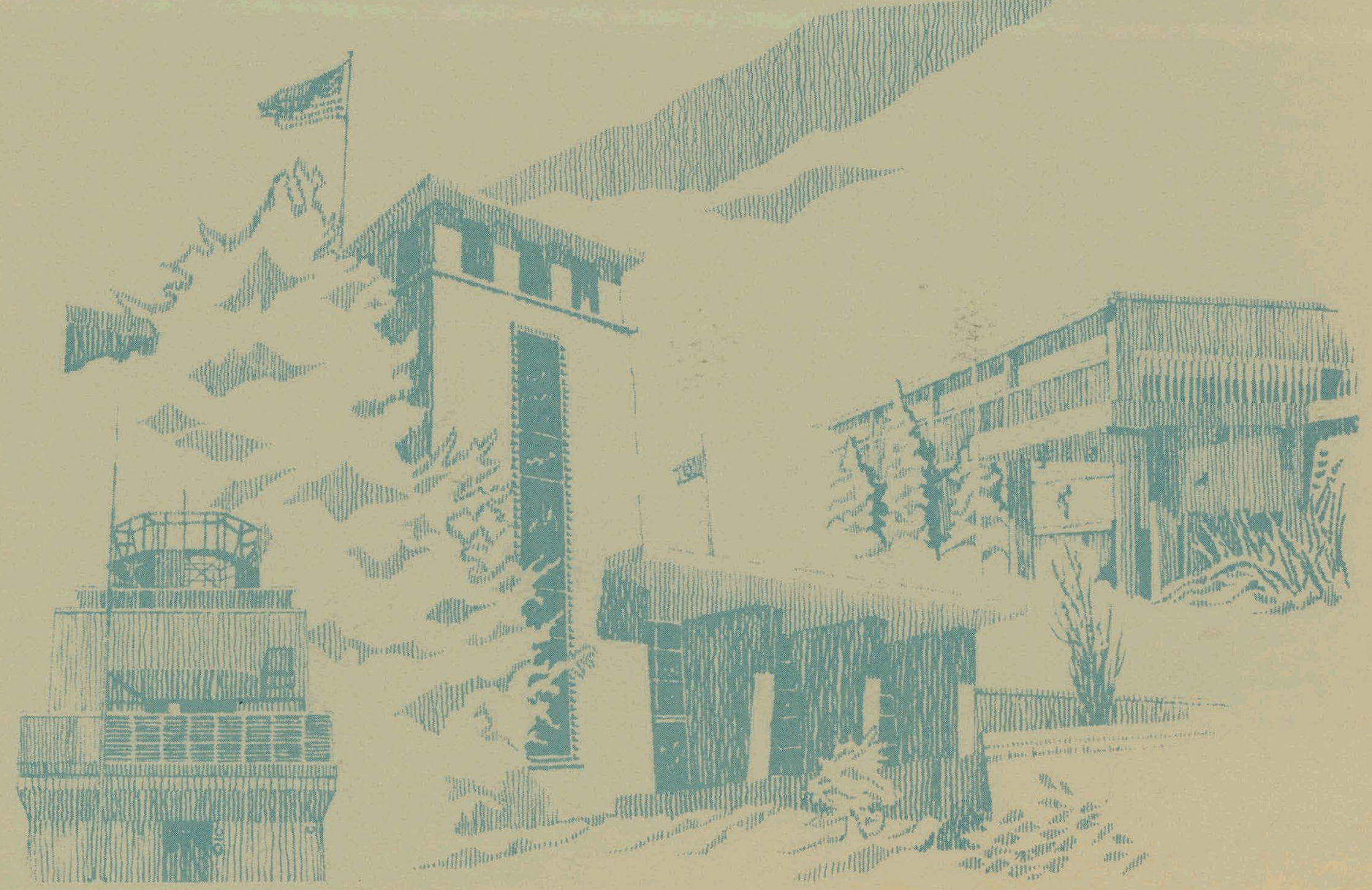




\section{DISCLAIMER}

This report was prepared as an account of work sponsored by an agency of the United States Government. Neither the United States Government nor any agency Thereof, nor any of their employees, makes any warranty, express or implied, or assumes any legal liability or responsibility for the accuracy, completeness, or usefulness of any information, apparatus, product, or process disclosed, or represents that its use would not infringe privately owned rights. Reference herein to any specific commercial product, process, or service by trade name, trademark, manufacturer, or otherwise does not necessarily constitute or imply its endorsement, recommendation, or favoring by the United States Government or any agency thereof. The views and opinions of authors expressed herein do not necessarily state or reflect those of the United States Government or any agency thereof. 


\section{DISCLAIMER}

Portions of this document may be illegible in electronic image products. Images are produced from the best available original document. 
Issued by Sandia National Laboratories, operated for the United States Department of Energy by Sandia Corporation.

NOTICE: This report was prepared as an account of work sponsored by an agency of the United States Government. Neither the United States Government nor any agency thereof, nor any of their employees, nor any of their contractors, subcontractors, or their employees, makes any warranty, express or implied, or assumes any legal liability or responsibility for the accuracy, completeness, or usefulness of any information, apparatus, product, or process disclosed, or represents that its use would not infringe privately owned rights. Reference herein to any specific commercial product, process, or service by trade name, trademark, manufacturer, or otherwise, does not necessarily constitute or imply its endorsement, recommendation, or favoring by the United States Government, any agency thereof or any of their contractors or subcontractors. The views and opinions expressed herein do not necessarily state or reflect those of the United States Government, any agency thereof or any of their contractors or subcontractors.

Printed in the United States of Americn Available fium

National Technical Information Service

U.S. Department of Commercc

5285 Port Royal Road

Springfield, VA 22161

NTIS price codes

Printed copy: $\$ 6.00$

Microfiche copy: A01 


\section{PAGES 1 to 2 WERE INTENTIONALLY LEFT BLANK}




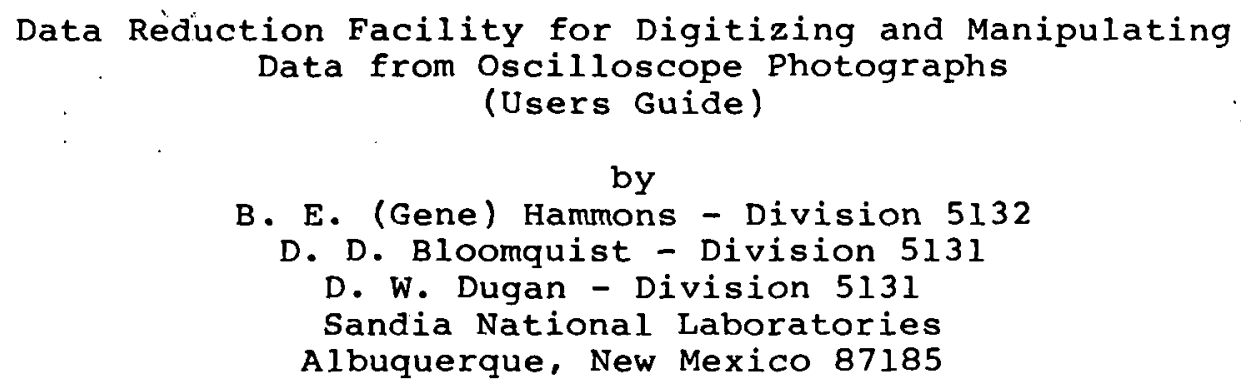

\section{Abstract}

An existing data reduction facility has been modified and upgraded to meet staff requirements. This facility is basically used to change the analog data recorded on oscilloscope photographs to digital information; which can be expanded, mathematically processed, replotted, stored for future reference, etc.

One of the main features of this facility is its capability to interact with Sandia's Network Operating System (NOS).

This report will describe the facility and its capabilities as well as guide the person operating the fasility. In essence, this report.will be the users manual for proper operation of the facility.

HOSTRIBUTION OF THIS DOCUMENT IS UNLIMITED

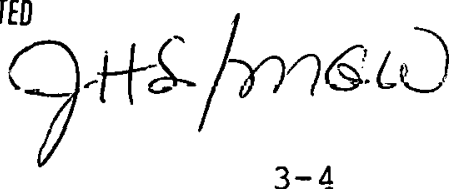




\section{Contents}

Abstract...................................

Introduction. ...........................

Facility Equipment......................... 9

Operational Procedures....................... 12

(1) Digitize a new file..................... 14

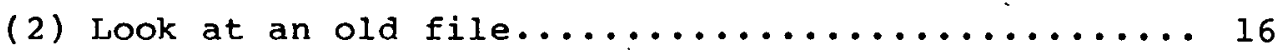

(3) Append some files together.................. 17

(4) Purge a file........................... 17

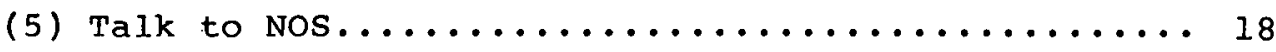

(6) Edit a data file........................ 19

Conclusion................................. 21

Appendix 1 - Hardware and Software Selection............ 22

Appendix 2 - Program Listing...................... 24 


\section{Introduction}

It is often necessary to analyze analog data from oscilloscope photographs, strip charts, or other graphical forms. Analysis of the data may involve conversion from analog to digital information. The digital information may be mathematically processed to extract the parameters needed for proper analysis of the original graph.

In the past, a data reduction facility was operated on a part-time basis by one individual. The facility has been modified and upgraded to make it suitable for more general use by staff personnel. 


\section{Facility Equipment}

A block diagram of the equipment in the data reduction room is shown in Fig. 1. The "heart" of the facility is an H.P. 9845T desktop computer. The computer controls the interaction of the other equipment and also communicates with Nos. A telereader and digitizer were modified and combined to form a single piece of equipment (see Appendix 1) which we will call the telereader-digitizer. This telereader-digitizer has, as its name suggests, two major functions. The first function is to enlarge graphs or photographs with the enlarged image focused on the digitizer platten. At present, three different lenses may be interchanged to obtain enlargements of approximately $1.5 \mathrm{X}$, $4.5 \mathrm{X}$ and $15 \mathrm{X}$. The second function of the telereader-digitizer is to provide a means of digitizing information from the enlarged photograph. This digital information is transferred to the computer in rectangular coordinate form (each digitized point has an $X$ value and a $Y$ value). The operator chooses the point to be digitized by placing a viewing port with crose-hairs over that point and depressing a switch conveniently located at the viewing port. Data and programs are stored on a dual floppy disk drive unit. Programs are stored on the left disk and data is stored on the right disk. A plotter is available to produce hard copy plots of the data. The data may be scaler to produce the desired size plot. A datacomm package and modem are provided for communication between the desktop computer and Nos. Data 


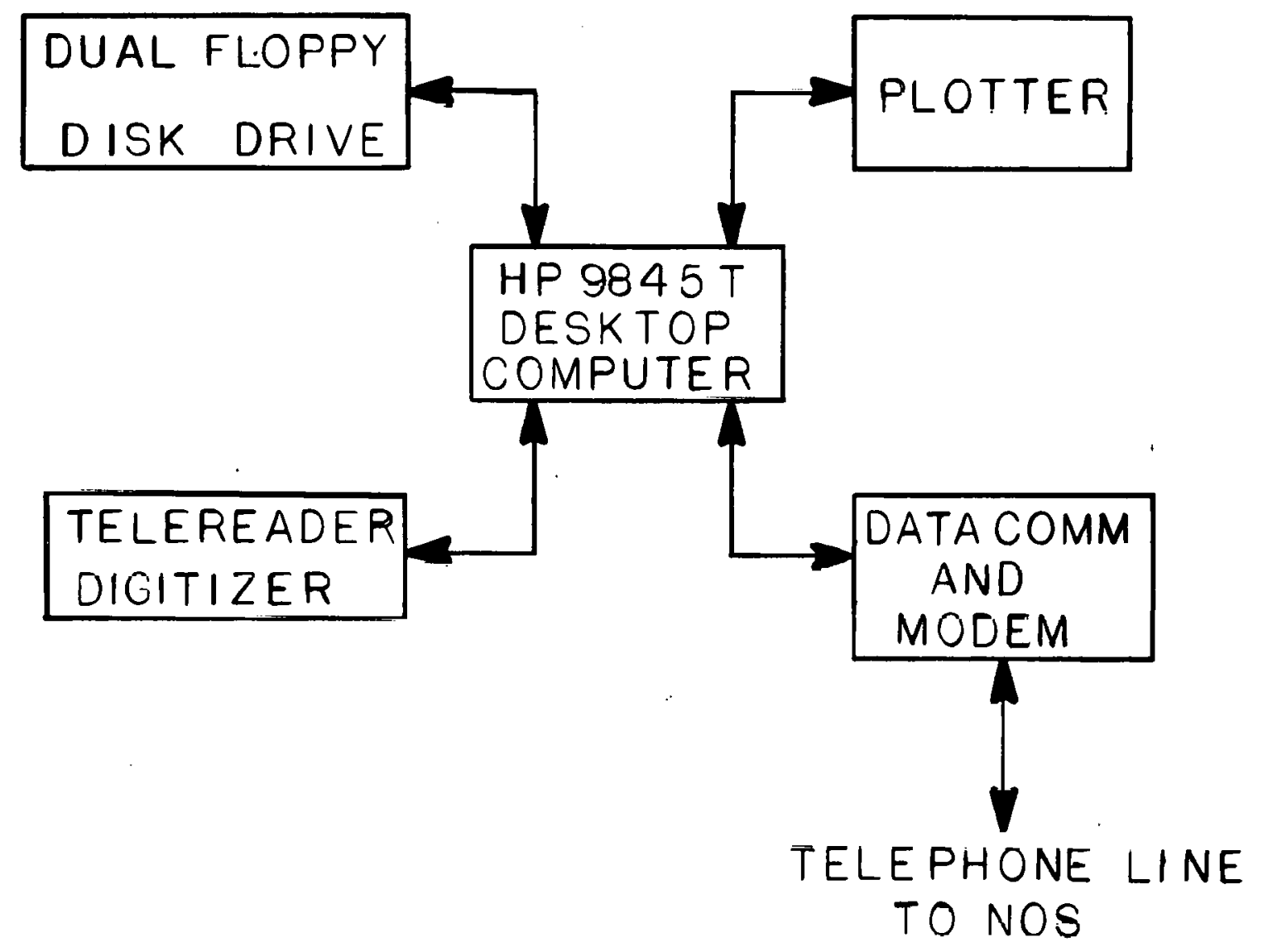

Figure 1. Block Diagram of Fquipment. 
may be sent to or from Nos at speeds approaching 1200 baud. Any standard Nos commands may be executed from the computer keyboard. When the computer is in datacomm mode (communicating with NOS) it responds as if it were a "smart" terminal with a CRT display of its interaction with NOS. Appendix 1 provides a detailed description of how the hardware and software were selected for this facility. It also lists the equipment purchased for the upgrade. 


\section{Operational Procedures}

This section deals with operation of the facility. For clarity we will assume you (the reader) will also be the operator. Due to the detailed description of the operational methods, it will be helpful for you to be in the data reduction room while reading this material. For a good understanding of the operational pronedures, 1 t will be beneficial for you to work with a qualifien operator and try each step as it is outlined.

A relatively large computer program has been developed to take the burden off the operator when reducing data. Under normal operating conditions you should have some general knowledge of how to use the telereader-digitizer and the computer. You will need to answer a few questions which appear on the CRT screen. However, the more difficult questions will be accompanied by an explanation or example of how to choose an appropriate answer. A flow chart of the computer program is shown in Fig. 2 and a complete software listing is located in Appendix 2.

The following procedure should be followed in setting up the facility to run the program:

1. Make sure no buttons on computer are depressed.

2. Turn on all equipment.

3. Place photograph in the telereader (enlarger).

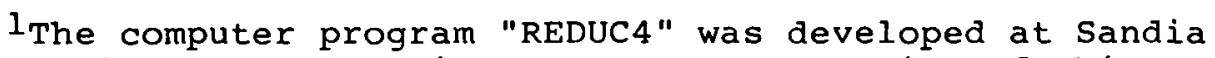
National Laboratories. However, a portion of this program was developed by the Hewlett Packard Company to operate the datacomm interface (H.P. Part No. 98046B).
} 


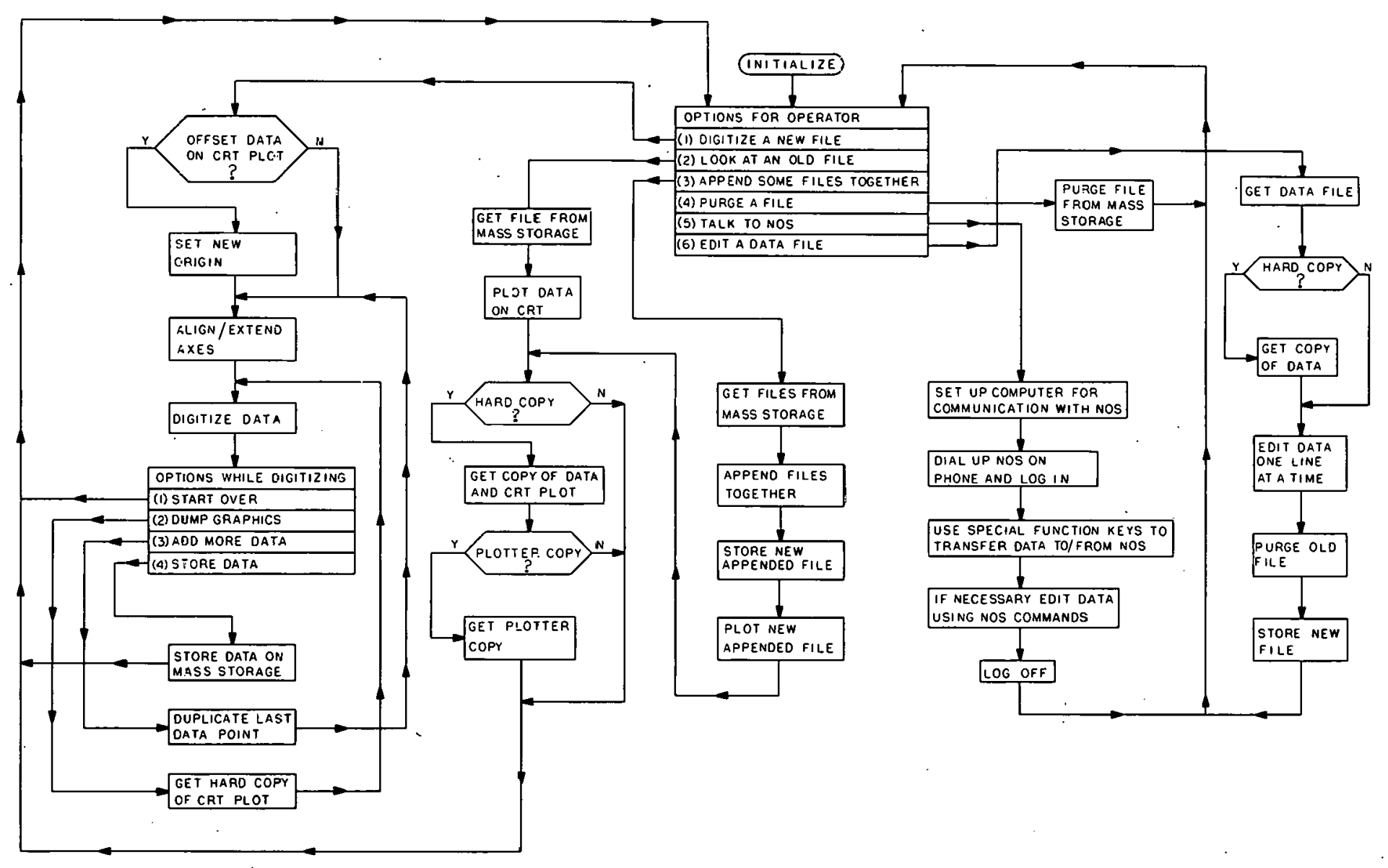

Figure 2. Flow Chart of Program 
4. Adjust lights in telereader for proper contrast on the digitizer screen.

5. On the keyboard, type LOAD "REDUC4:H8,0,0", 10.

6. Press EXECUTE on the keyboard.

After the program has finished loading, the computer will ask: "WOULD .YOU LIKE TO:"

(1) DIGITIZE A NEW FILE

(2) LOOK AT OLD FILE

(3) APPEND SOME FILES TOGETHER

(4) PURGE A FILE

(5) TALK TO NOS

(6) EDIT A DATA FILE

We will deal with each of these options in detail to ald you in making the proper decisions. If at any time you get lost, simply press STOP, type CONT start, and press EXE'CUI'E. However, by doing so; data in the computer memory may be destroyed. The program will be started again from the beginning.

\section{(1) DIGITIZE A NEW FILE}

If, at start-up conditions you press 1 , then cunil, you have chosen to digitize a new file. The computer will now ask: DO YOU WANT TO OFFSĒT YOUR DATA UN CK'L YLUT? (Y OR N). If your answer is $\underline{Y}$, then the computer will ask: WHERE WOULD YOU LIKE THE ORIGIN? YOur answer, according to the instructions on the CRT, may be $\underline{I}, \underline{2}, 3$, or $\underline{4}$. Only your displayed data will have the new origin you have selected. This may be necessary because the CRT will only plot in the positive quadrant. The actual data stored in memory will not be offset. 
The computer will now state: YOU MAY NOW ALIGN/EXTEND YOUR AXES. PRESS CONT TO PROCEED. The ALIGN/EXTEND procedure is used to establish a base line to which all the digitized data will be referenced. In other words, you are establishing the $\mathrm{X}, \mathrm{Y}$ coordinate system. The first point you digitize will be the origin 0,0 and the second point you digitize will be any $X$ value along the $\mathrm{Y}=0$ axis. If you do not wish to ALIGN/EXTEND your axes, i.e. you are using the same photograph with another trace, then simply press CONT. You are now ready to digitize your data. Place the viewing port with cross-hairs directly over the point you want digitized. Press the digitize button and move on to the next point. You may digitize up to 1999 data points.

During the course of digitizing your data, you have several options as to the disposition of your data. Notice the top of the computer screen which references the special function keys ( $f a ; f b, f c, f e$ ) located on the digitizer. While digitizing data, you may press any one of these keys.

1. Key fa - START OVER: By pressing this key you will cause the computer to forget all previously digitized data and start the program over.

2. Key fb - DUMP GRAPHICS: Pressing fb causes the printer to print whatever is on the CRT. No data will be lost and you may resume digitizing as soon as the printer is finished. 3. Key fC - ADD MORE DATA: Use this key as an end of record mark if several different records or graphs are to be 
stored in one large file such as in VISAR records. This key simply duplicates the last data point which was digitized and allows the user to put in a different graph and realign the axes.

4. Key fe - STORE DATA: Use this key when you are ready to store your digitized data on mass storage. The last digitized point will be duplicated. Then; you will be asked for a PERMANENT FILE NAME. The name you provide (up to 6 characters long) will be used as the permanent file name and the digitized data will be stored on mass storage. The program will then return to start-up conditions.

\section{(2) LOOK AT AN OLD FILE}

If, at start-up conditions you press 2, then CONT, you have chosen to look at an old data file. Next, you will be asked the NAME OF DATA FILE. Then, since the data will be plotted on the CRT, you will be asked: "DO YOU WANT TO OFFSET DATA TO FORCE IT INTO $+X,+Y$ QUADRANT?" After the computer has received your answer, it will go ahead and plot the data on the CRT. After looking at the plot, you will need to press CONT to proceed. You will be asked: "DO YOU WANT A HARD COPY? ( $Y$ OR $N$ )". If your answer is $\underline{Y}$, the printer will print a copy of what was on the screen. Next, you will be asked: "DO YOU WANT A PLOTTER COPY? ( $Y$ OR N)". If your answer is $\underline{Y}$, the computer will go to a plotting subroutine, and you will need to follow the instructions on the CRT. The program will then return to start-up conditions. 


\section{(3) APPEND SOME FILES TOGETHER}

If you have chosen to append some files together, the computer will ask: "HOW MANY FILES DO YOU WISH TO APPEND?" In other words, how many small files do you wish to add together to make one large file? The computer will then ask for the first FILE NAME. The CRT will keep you updated as to the last. file you appended and how many more you have to append. After all the files have been appended, you will be asked to give a PERMANENT FILE NAME for the new file. The new file will then be stored on mass storage. Your new data file will now be plotted on the CRT. After you have viewed the plot, press CONT to proceed. You will be asked: "DO YOU WANT A HARD COPY? (Y OR N)". If your answer is $\underline{Y}$, the printer will print a copy of your data and the CRT plot. Next, you will be asked: DO YOU WANT A PLOTTER COPY? ( $Y$ OR $N$ )". If your answer is $\underline{Y}$, the computer will go to a plotting subroutine, and you will need to follow the instructions on the CRT. The program will then return to startup conditions.

\section{(4) PURGE A FILE}

If you have selected option (4), the computer will ask: "WHAT IS NAME OF FILE YOU WISH TO PURGE?" This file will then be purged from mass storage. You will then be așked: "DO YחII WISH TO PURGE ANOTHER FILE" ( $Y$ OR N)". If your answer is $\underline{Y}$, the above process will be repeated. If your answer is $\underline{N}$, the program will return to start-up conditions. 


\section{(5) TALK TO NOS}

If you have chosen to talk to Nos, the computer will get set up for data communication and tell you it is waiting for connection. At this time you will need to dial 351 and place the phone receiver in the modem. Next, log in using your normal Nos $\log$ in procedure. You may now communicate with Nos in the normal manner using the standard Nos commands. You may also use the special function keys on the computer keyboard. We will now briefly discuss the use of some of the more frequently used special function keys.

1. Shift/Key 6 - Cat H8,0,0: Use this key to get a listing of the files from the left floppy disk.

2. Shift/Key 7-Cat H8,0,1: Get a listing of data files from the right floppy disk.

3. Key 8-Break: Interrupt communication with Nos.

4. Key 12 - Del Line: Delete the line you are typing.

5. Ghift/Kcy 12 - Groate: Ereate spare for a file on mass storage before getting and recording that file from Nos.

6. Shift/Key 13 - Purge: Purge a file from mass storage.

7. Shift/Key 14 - Upload: Senda a Nlle frum Illas sluiage to NOS.

8. Shift/Key 15 - Record: Get a file from Nos and record it on mass storage.

A more detailed instruction set for the special function keys can be found in the H.P. data communication documentation manual. 
If you get lost while talking to Nos̀ or push the wrong key, it may be necessary to restart the program. To restart the program, press CONTROL STOP. Next, press RUN. Then type $\underline{5}$ and press CONT. Press $\underline{\text { CONT }}$ again and the computer should resume communications with Nos. You do not need to 109 in again, simply resume your conversation with NOS. You may log off at any time in the usual manner.

\section{(6) EDIT A DATA FILE}

This routine provides simple line substitution editing. You should only use this option for replacing a few spurious data points in your file. Use NOS if much editing is to be done. The computer will ask: "NAME OF DATA FILE?". When you have given the computer a file name, it will get that file from mass storage and ask: "WOULD YOU LIKE A HARD COPY OF THE DATA?". If your answer is $\underline{Y}$; then a listing of the data will be printed on the printer. You will be asked to: "ENTER OLD $\mathrm{X}, \mathrm{Y}$ PAIR TO BE REPLACED LIKE THIS: X:+00012 Y:-00123". It is important to enter the $X, Y$ pair in the proper format (just like it is shown on the print out). Next you will be asked to: "ENTER NEW X, Y PAIR IN THE SAME FORMAT: X:+00012 Y:-00123". The computer will then replace the old pair with the new pair and ask: WOULD YOU LIKE TO CHANGE ANOTHER POINT?"

If your answer is $\underline{Y}$, the process will be repeated. If your answer is $N$, the computer will purge the old data file from mass storage and save the new edited file using the same file name. The program will then return to start-up conditions. 
REMEMBER:- Under normal çonditions you may stop and restart the program by pressing STOP, then typing CONT Start, and pressing EXECUTE. However, if at any time the computer seems to have locked up (will not respond to keyboard commands), you will need to reset it. To do this, press CONTROL STOP. Next press RUN. You should now be back to start-up conditions. However, any time you press CONTROI. STOP, you will lose any data stored in memory. You will also abort any input/output uperations which may result in the loss of a data file on mass storage. Therefore, only use CONTROL STOP when absolutely necessary. 


\section{Conclusion}

Digitizing waveform information from oscilloscope photographs may be relatively easy, or very tedious and time consuming, depending upon the number of digitized points and the required accuracy. In the past, detailed training of a single operator was necessary for quality work. With the modifications, new equipment, and new software, only minimal training is now necessary for the more casual user to produce quality work which may be tailored to fit his/her particular requirements. Digitized data may be printed, plotted, edited, scaled up or down, offset, stored on a local mass storage unit, or sent to and retrieved from Nos. Once the data is resident at Nos, any standard Nos commands may be used to manipulate the data.

The equipment in the data reduction room, like any other electro-mechanical equipment, is subject to wear and eventually failure. Any problems with the equipment should be reported to the 5131 division supervisor. Also any helpful suggestions for future facility improvements would be appreciated. 


\title{
Appendix 1
}

Hardware and Software Selection

\begin{abstract}
A considerable amount of redesign, upgrading of old equipment, and purchase of new equipment was necessary to meet staff requirements for the facility. The choice of new equipment was largely influenced by the availability of digitizers which could be modified and interfaced with an optical photograph enlarger. After a rather extensive search, the H.P. 9874A digitizer was selected for the following reasons:

1. Tt.s translucent platen, similar to ground glass, would allow for a rear screen projection system.

2. It had the capability of transferring a point from one side of the platen to the other, which wiuld allow for axis extension up to several feet. This feature was necessary for the reduction of data from strip charts.

3. It provided extremely high 'resolution (up to 5 significant digits with resolution of $25 \mu \mathrm{m})$.

4. It was physicaliy compatble with the existing telereader. The telereader is an optical projector which uses high quality interchangeable nptics to vary magnification of the image.

During the digitizer selection process; other facility equipment was evaluated with emphasis on interfacing compatibility. The aim was to provide a complete system delivered, interfaced, and easy to use. The H.P. 9800 series equipment met these
\end{abstract}


requirements and the published literature indicated good performance should be expected when used in the data reduction facility. The components chosen for the facility were as follows :

1. $9874 \mathrm{~A}$ Digitizer

2. $9845 \mathrm{~T}$ Desktop computer

3. 9895A Double dual-sided floppy mass storage

4. $98046 \mathrm{~B}$ Terminal emulator

5. $9872 \mathrm{~B} 4$ pen plotter

6. 98035A Real. time clock

7. $98034 \mathrm{~A}$ HPIB interface bus

Some software was included with the above equipment and some additional software was purchased from H.P. to provide proper communication with a large host computer such as Sandia's Network Operating System (NOS). Unfortunately due to some inconsistencies in software, much of the H.P. software had to be rewritten. A large portion of new software was also written and integrated with the H.P. software to provide a versatile user oriented data reduction program. A copy of the software is located in Appendix 2. 


\section{APPENDIX 2}

Program Listing

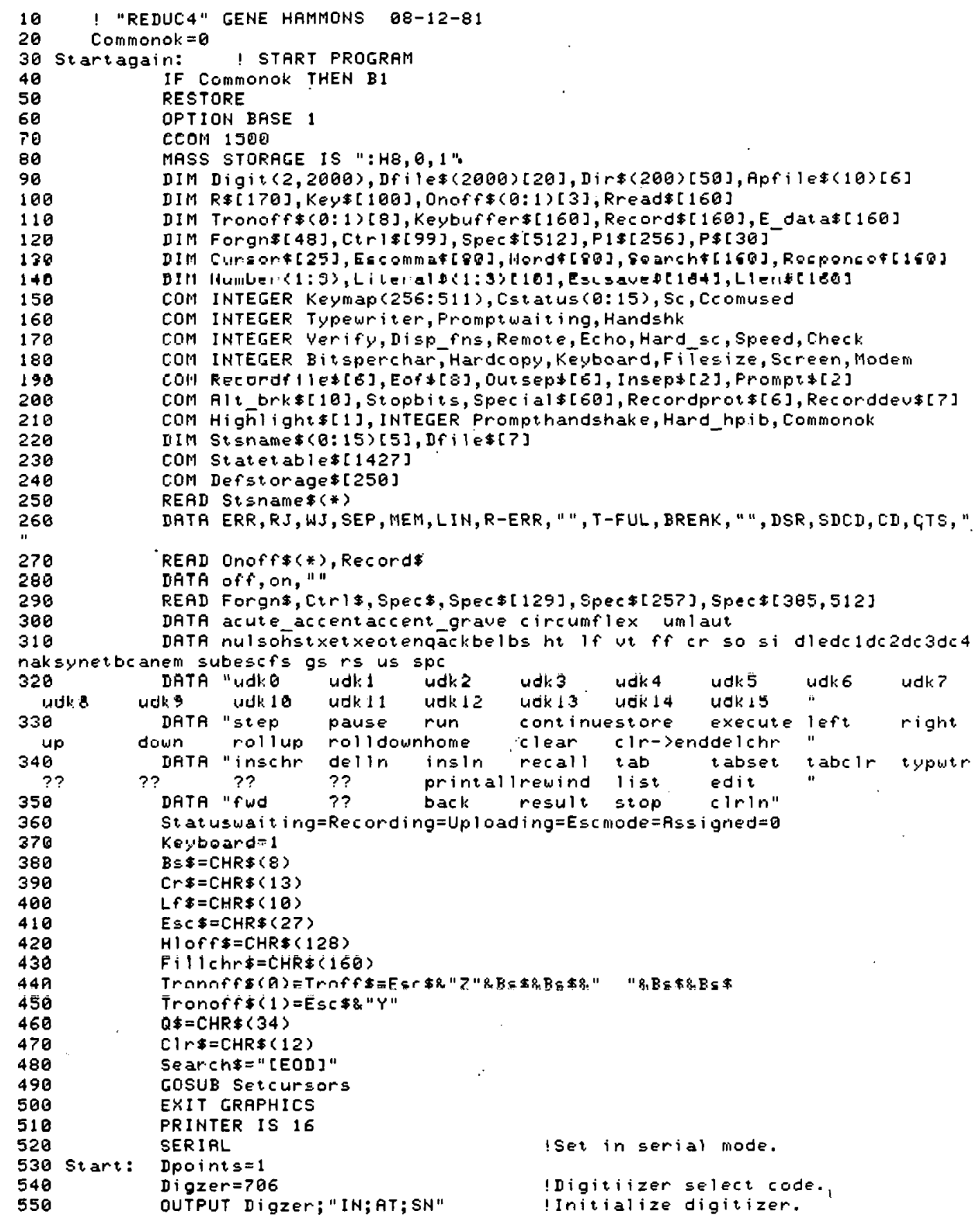




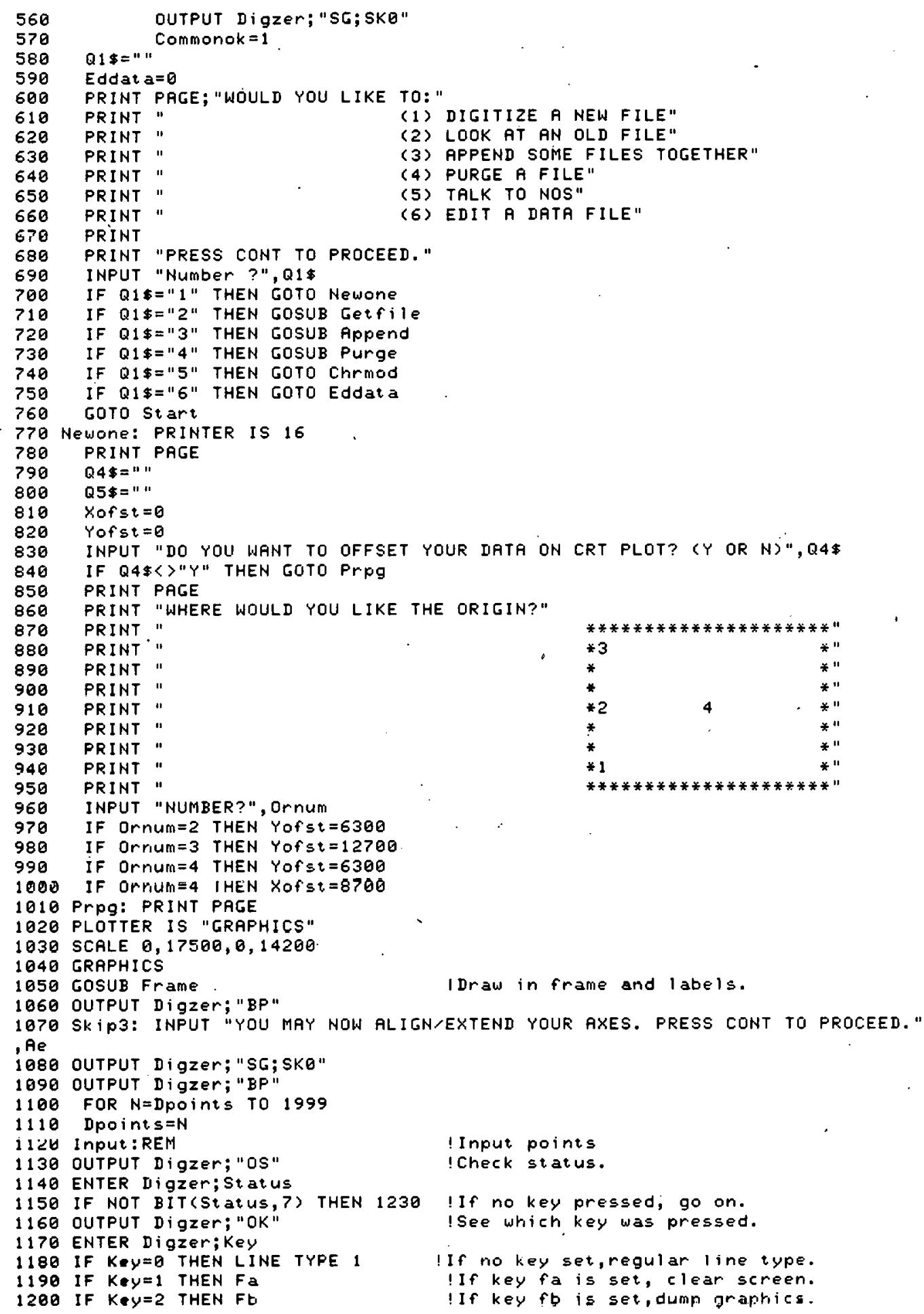




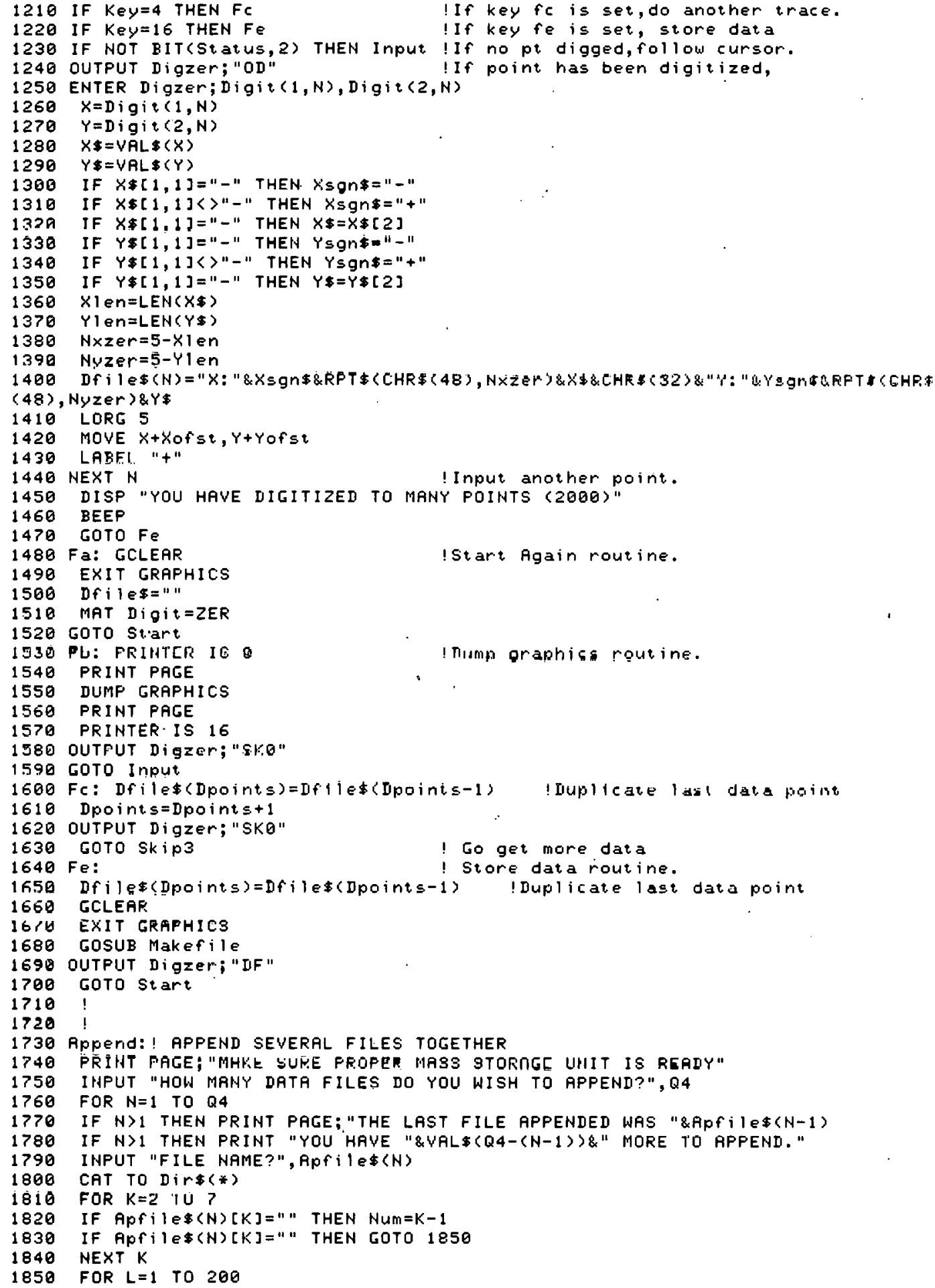




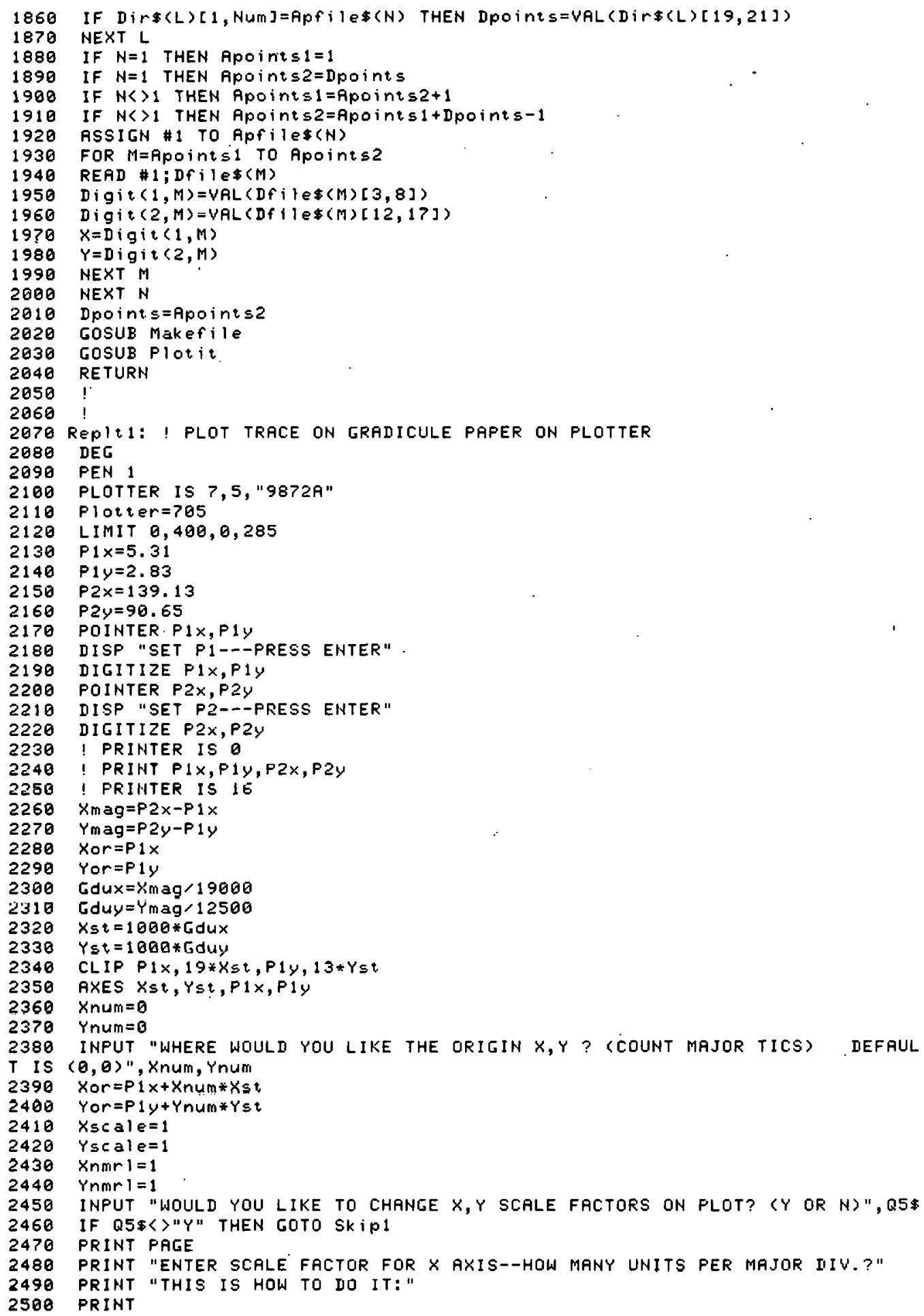




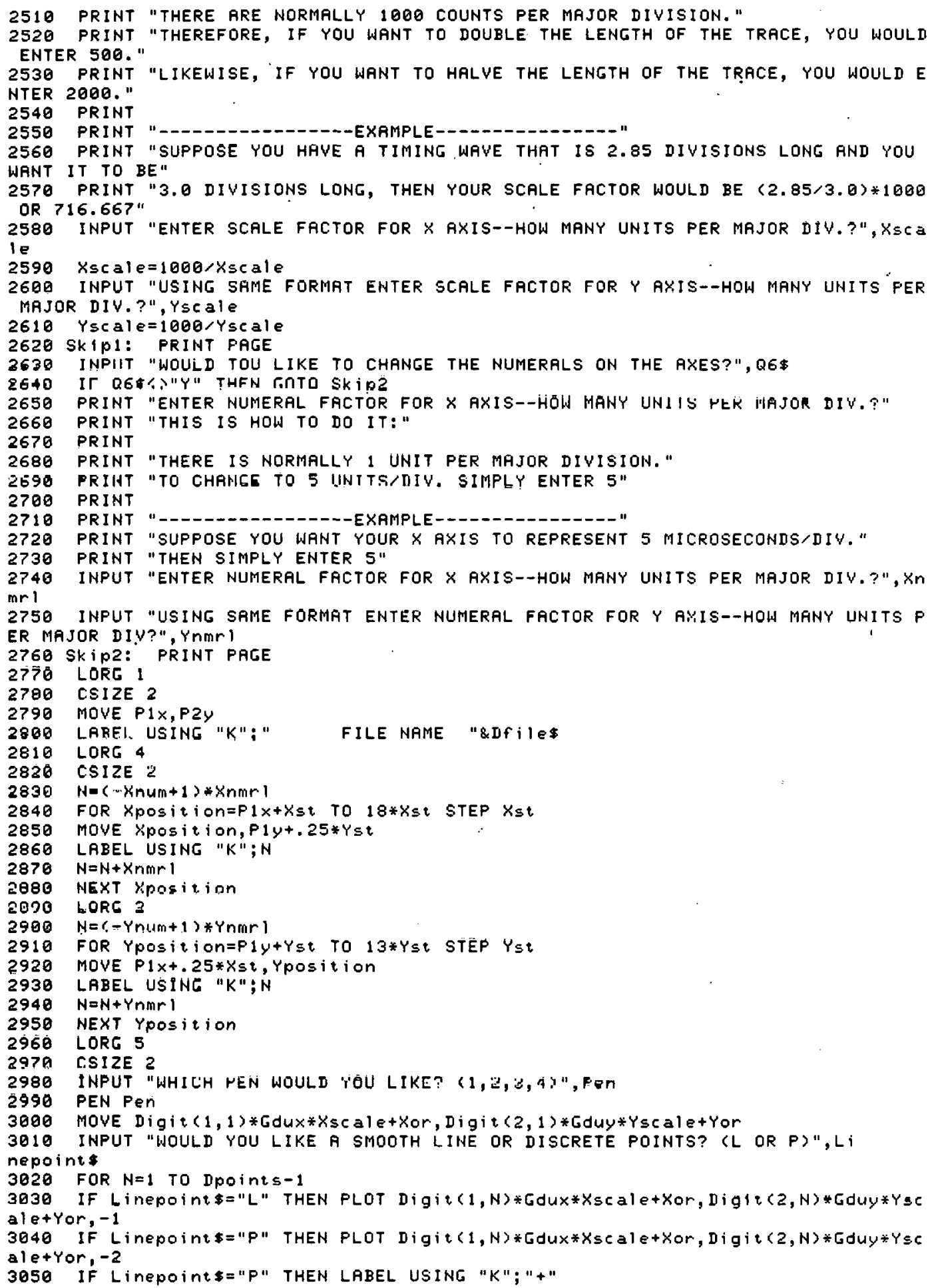




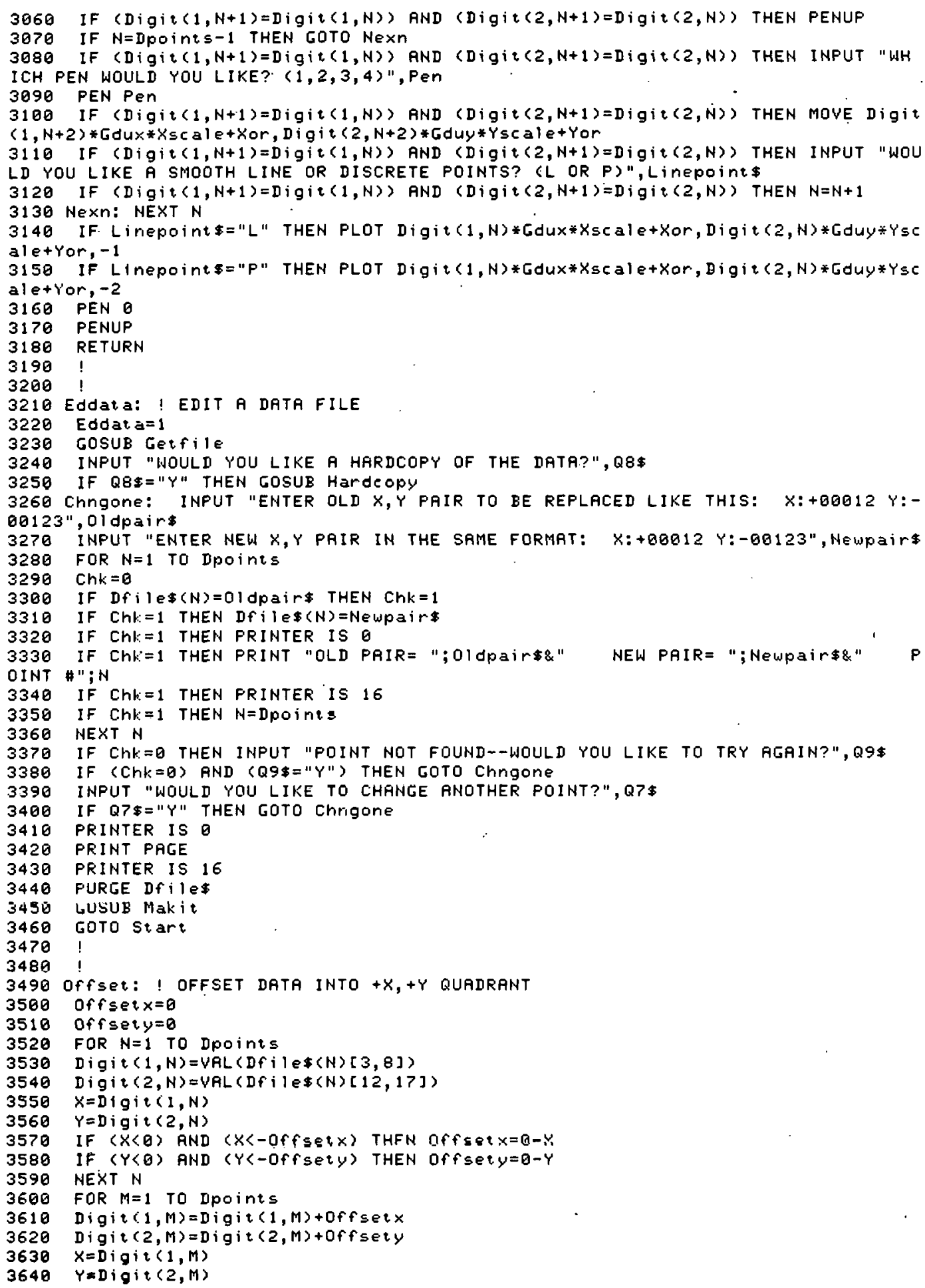




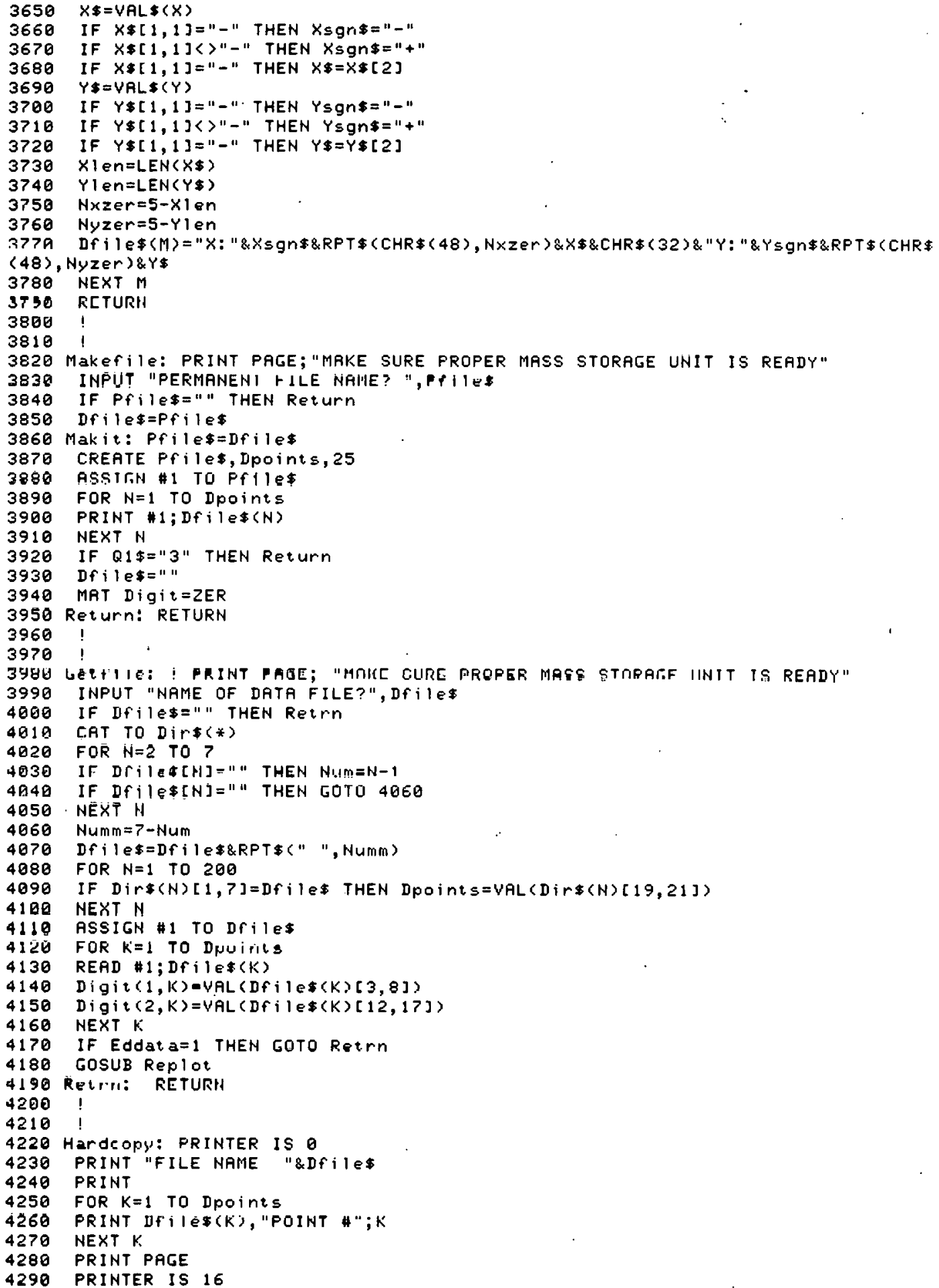




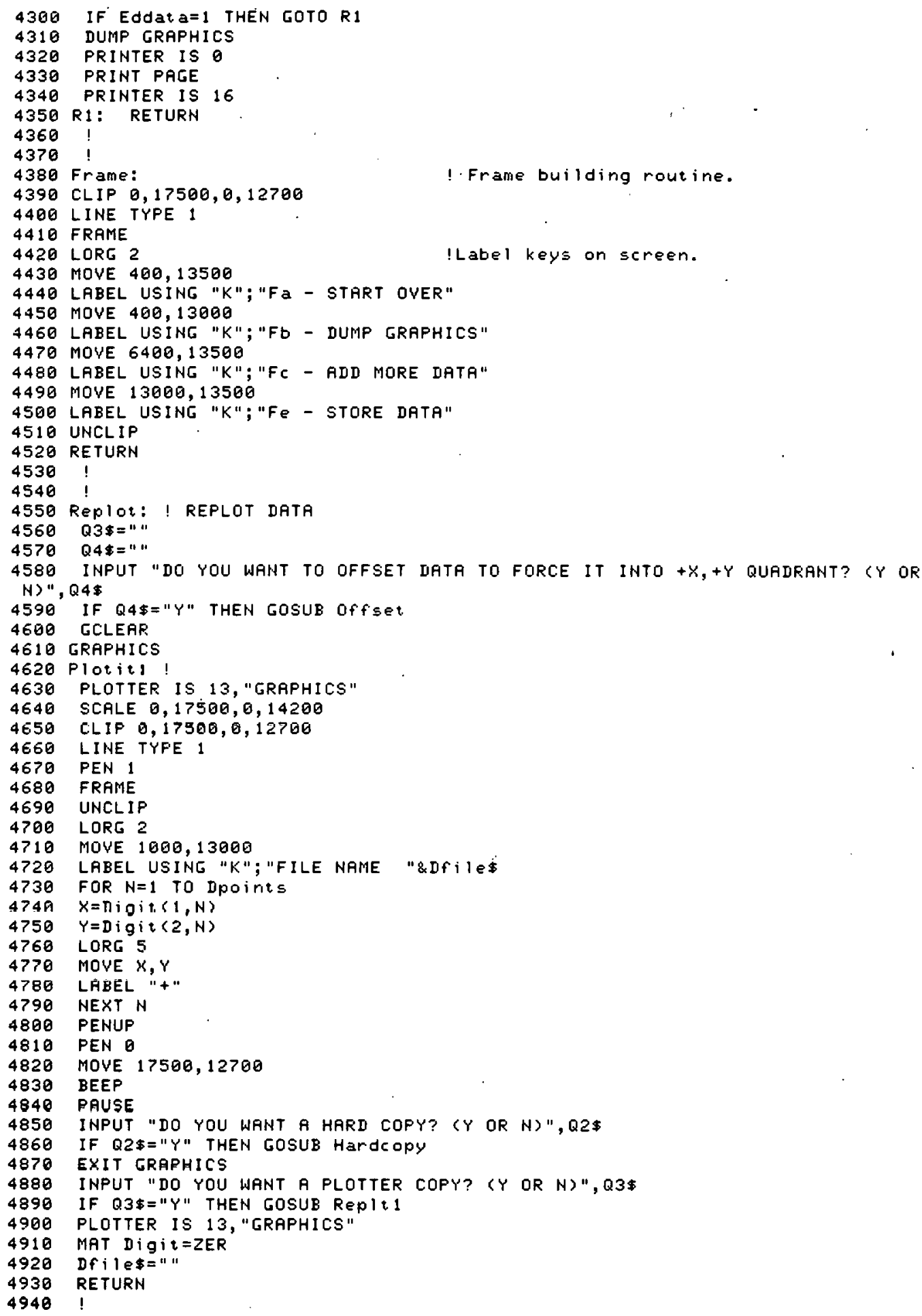

!- Frame building routine.

! Label keys on screen. 
4950

4960 Purge: INPUT "WHAT IS NAME OF FILE YOU WISH TO PURGE?", Purg\$

4970 ON ERROR GOTO E56

4980 PURGE Purg\$

4990 E56: IF ERRN=56 THEN INPUT "FILE NOT FOUND. PRESS CONT TO GO ON.",OK

5000 EDIT "DO YOU WISH TO PURGE ANOTHER FILE? (Y OR N)", Q5\$

5010 IF Q5\$="Y" THEN GOTO Purge

5020 RETURN

5030

5040

5050 Chrmod:

5060 ! 9845 Character mode High speed asynchronous terminal emulator

5070 PRINTER IS 16

5080 STANDARD

5090 DISP "Initializing"

5100 Defaults:RESTORE Defaults

5110 READ Hard sc, Screen, Filesize, Bitsperchar, Check, Speed

5120 DATA $0, \quad 16, \quad 10, \quad 3,1200$

5130

READ Modem, Recorddeus, Recordprit

DATA $1, "$ : H8, 0,1"

Recondlen-36

Defstorage $\$="$ "

Out $s \in p \$=6 r \$$

Insep $\$=C r \$ \& L f \$$

Prompt $\$=C H R \$(47)$

Highl i ghe $\$$ aCHR $\$(120)$

Alt brk $\$=C H R \$(25)$

Eof $\overline{\$}=\mathrm{CHR}(\theta) \& \mathrm{CHR} \Phi(\theta) \& C H R \$(3) \& 0 u t$ sep $\$$

GOSUB Setall

Harde opy $=$ Ver if $y=I$ isp fns $=$ Typewrit er $=0$

Stopbit $s=2$

Handshk $=0$

Prompthandshake $=$

- Remote $=$ ECho=Commonok $=1$

CHECK READ OFF

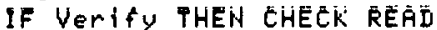

B1: PRINTER IS SCrEeN

TYPEWR ITER DFF

IF Typewriter THEN TYPEWRITER OH

If SC<2 THEN B 4

UN LSIHI(SE, S)+2 LUIU B4, 44, BZ, B7, BE

GOOUD DO D

GOTO B?

$\mathrm{Sc}=4$

$S C=S C$ DIV $2 * 2$

GOSUB Domodel

If Cmodelerror $\langle>1$ THEN $B$ ?

DISP "Disconnecting"

UN FRROR GOTT RS

FOR SC=2 TO 12 STEP 2

CDISCONNECT SC

B5: NEXT SC

$T=0$

FOR $S C=2$ TO 6 STEP 2

UN ERRUR GUTU B6

CMODEL ASYNC, SE:MEMLIMIT=0, INBUFFER=0, TBLIFFER=0

LUISLUUNALL'T SE

ÜFF ERRŨR

IF T THEN B3

$T=3 L$

B6: GOSUB Do_6

NEXT Sc

SE $=T$

IF T THEN B4

DISP "No 98046 cards installed."

STOP 


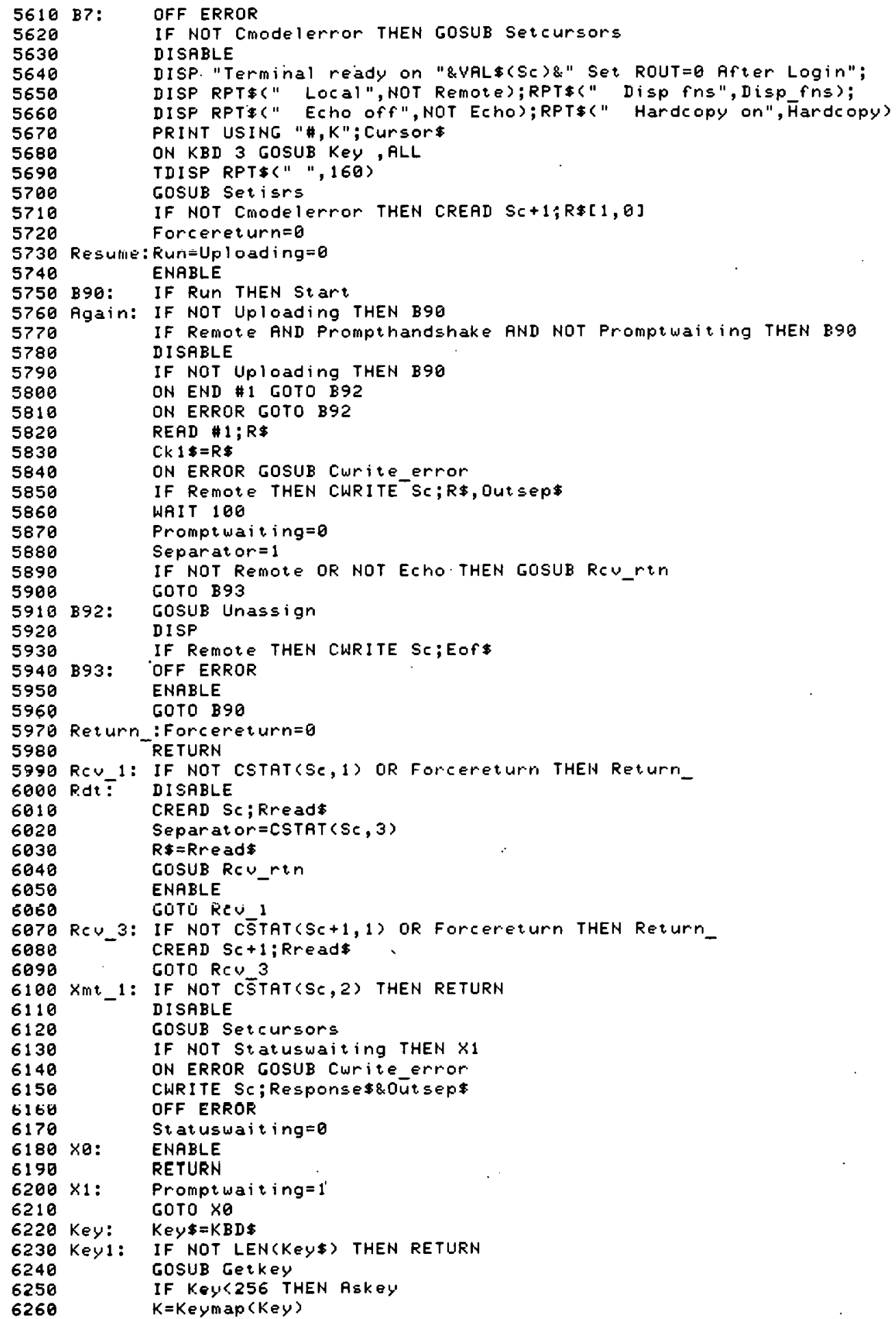




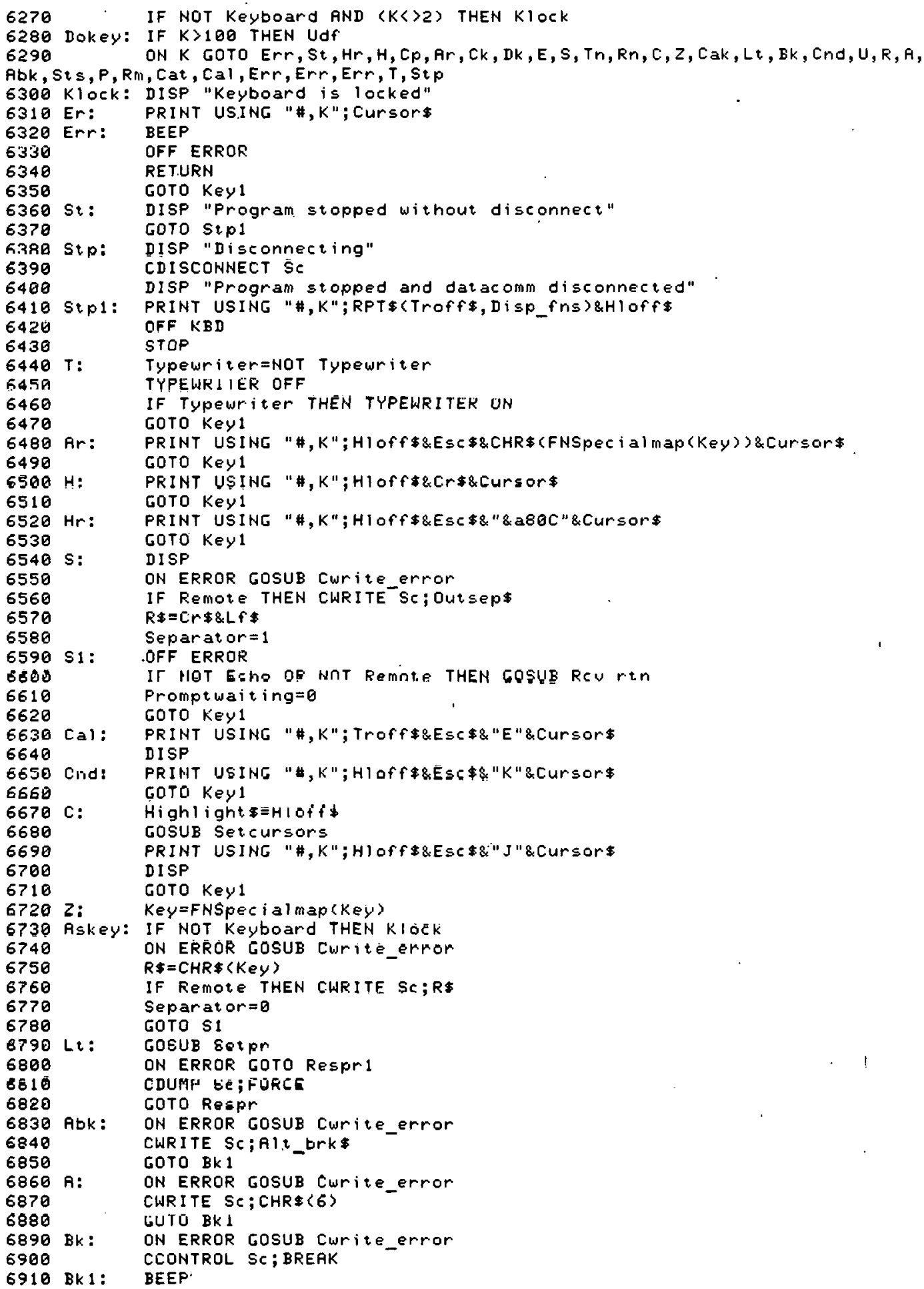




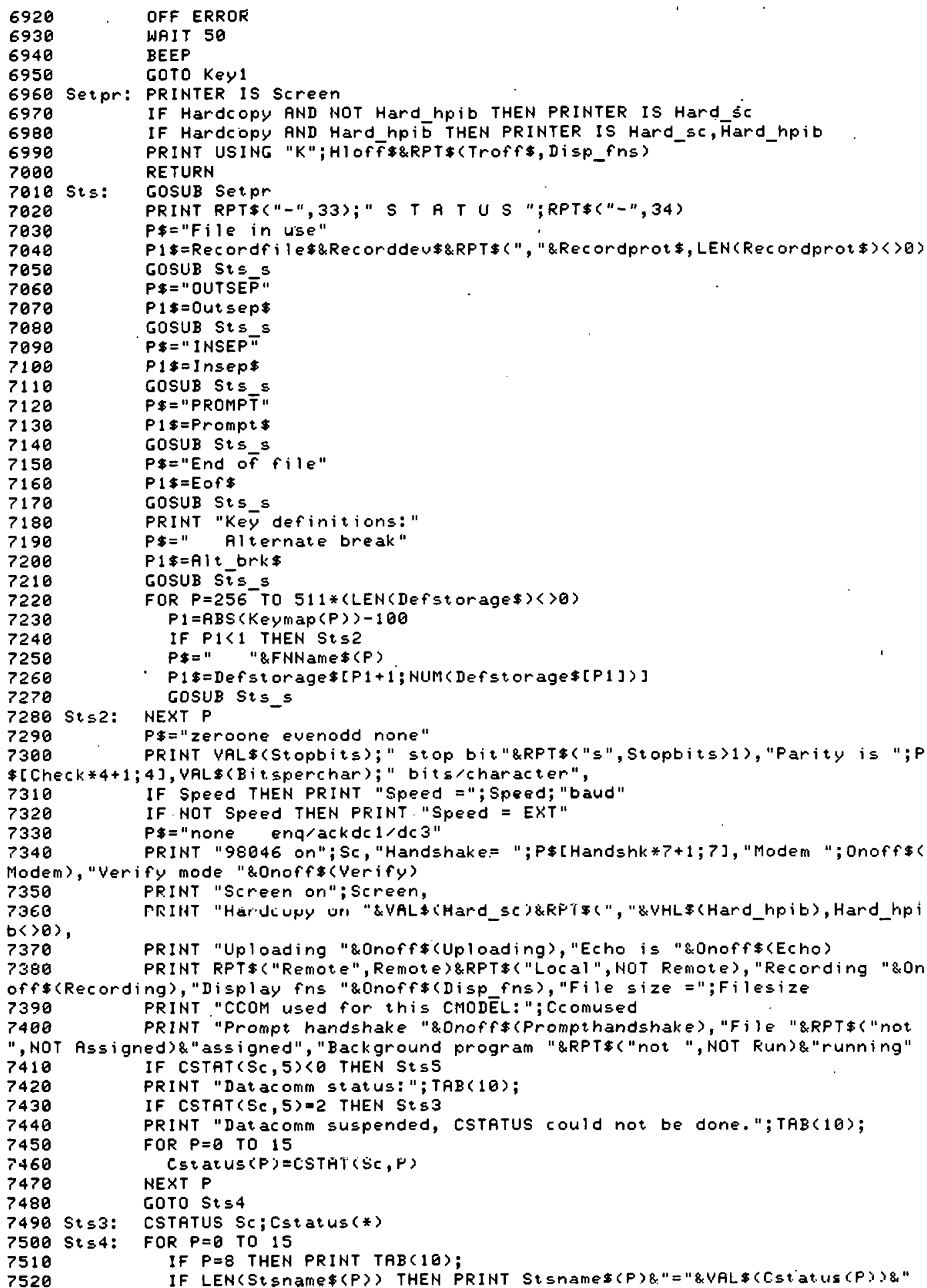




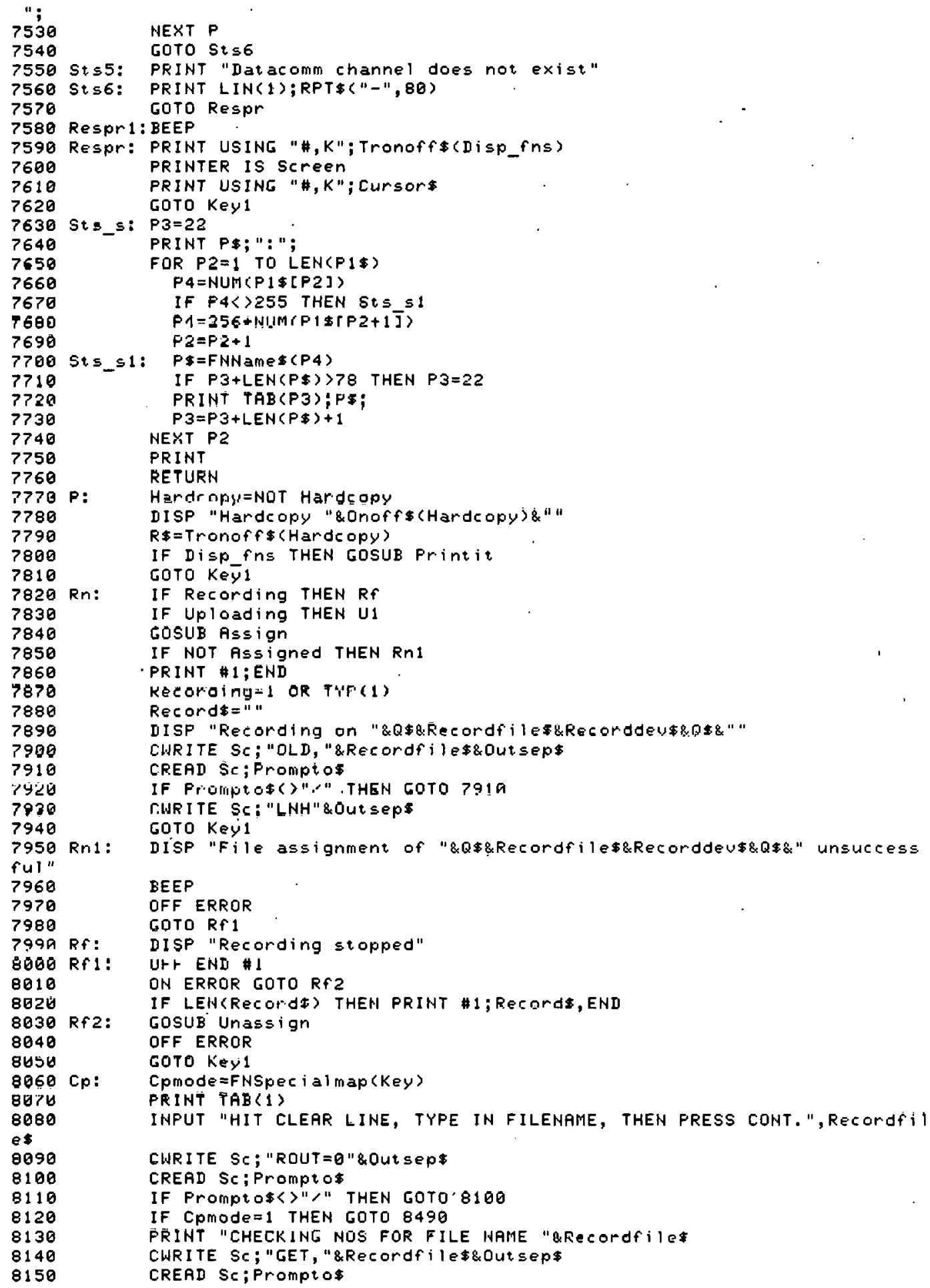




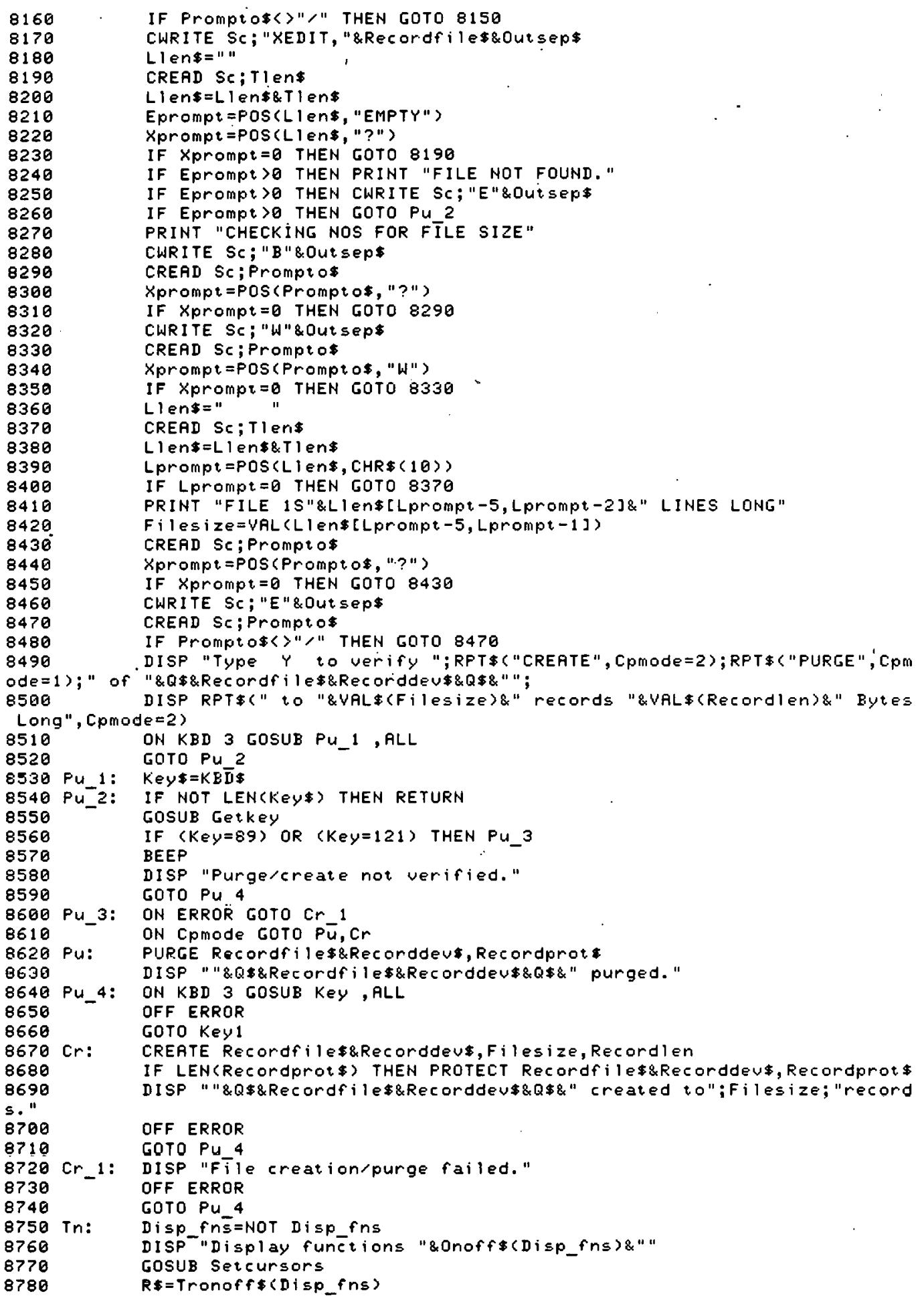




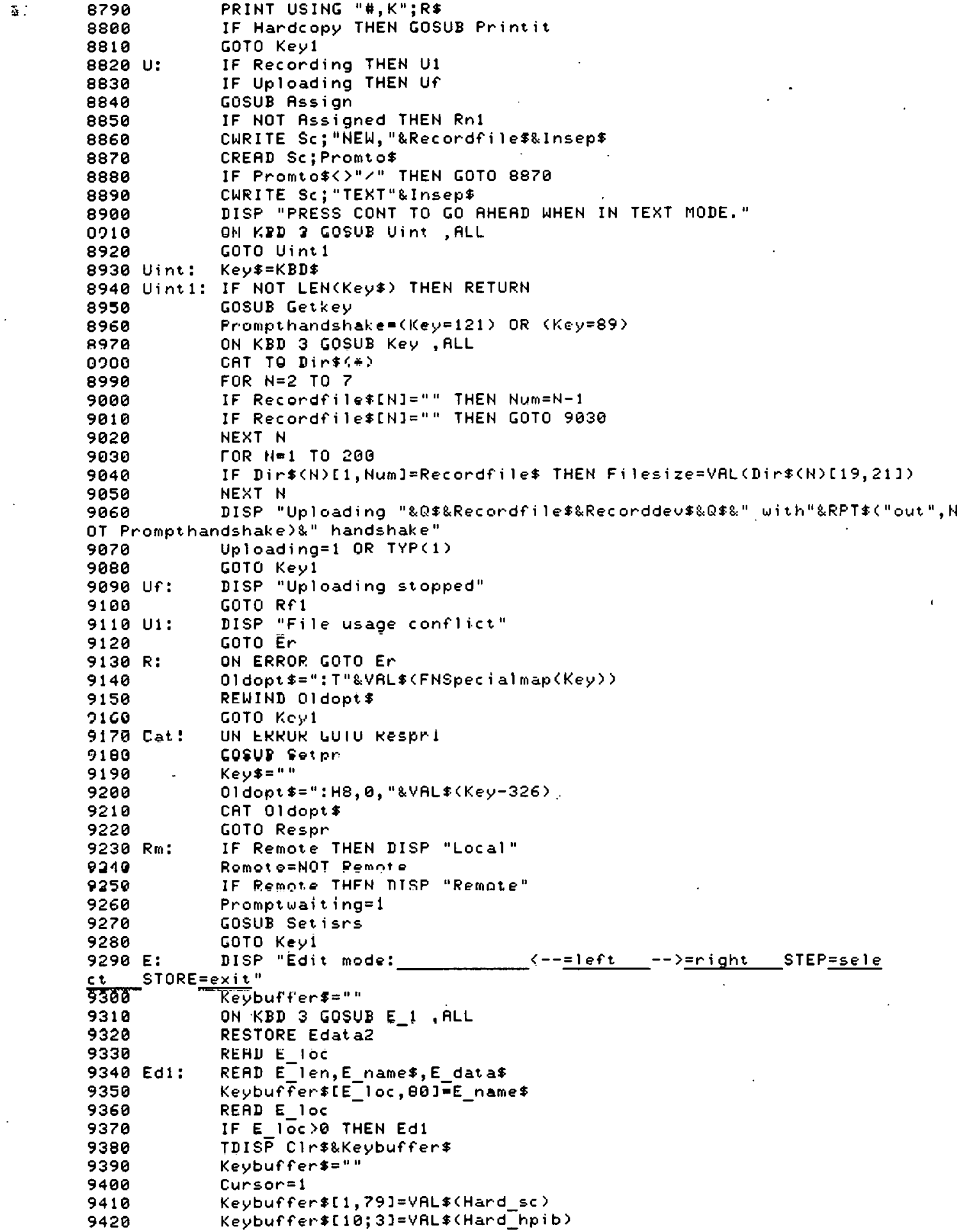




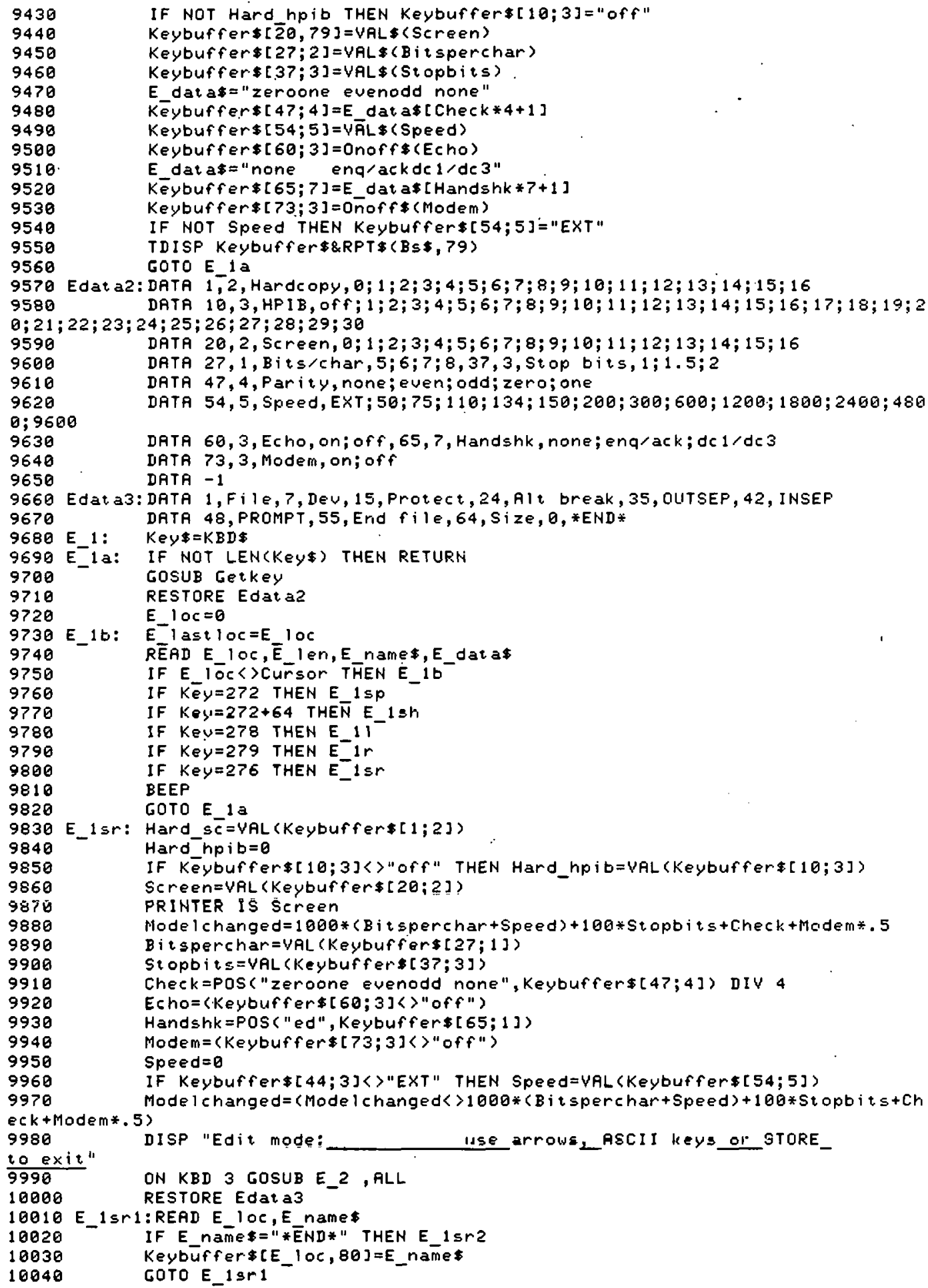




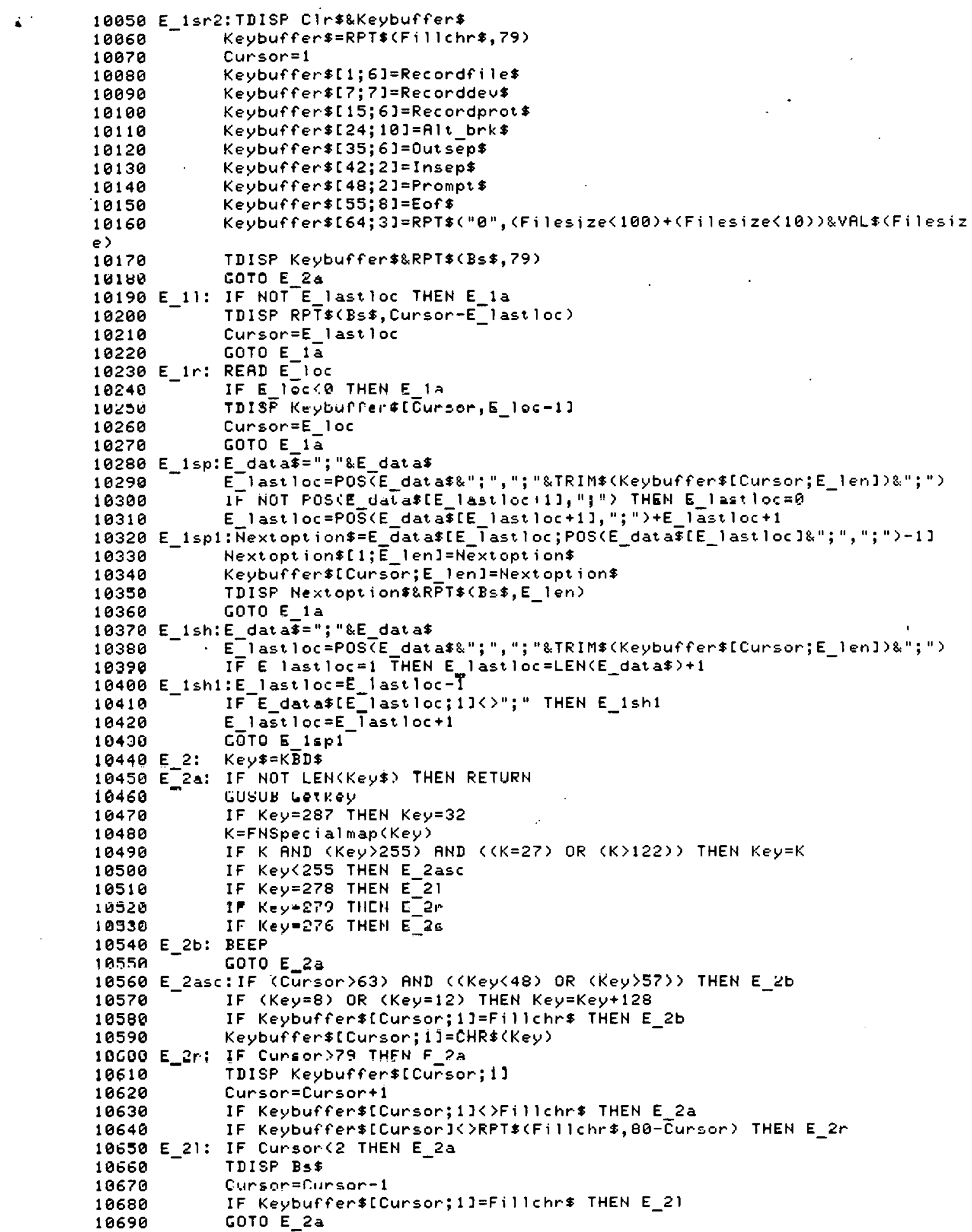




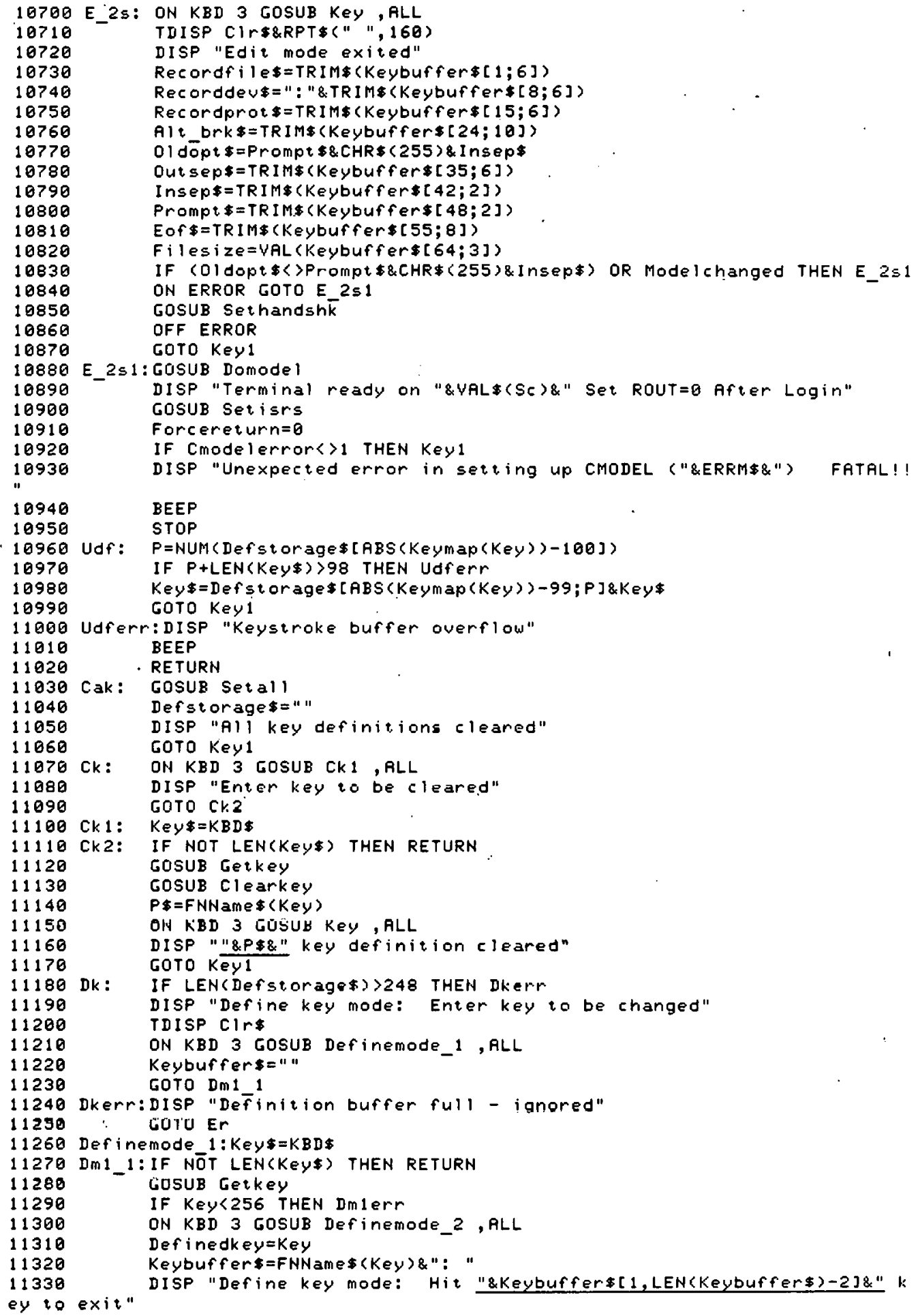




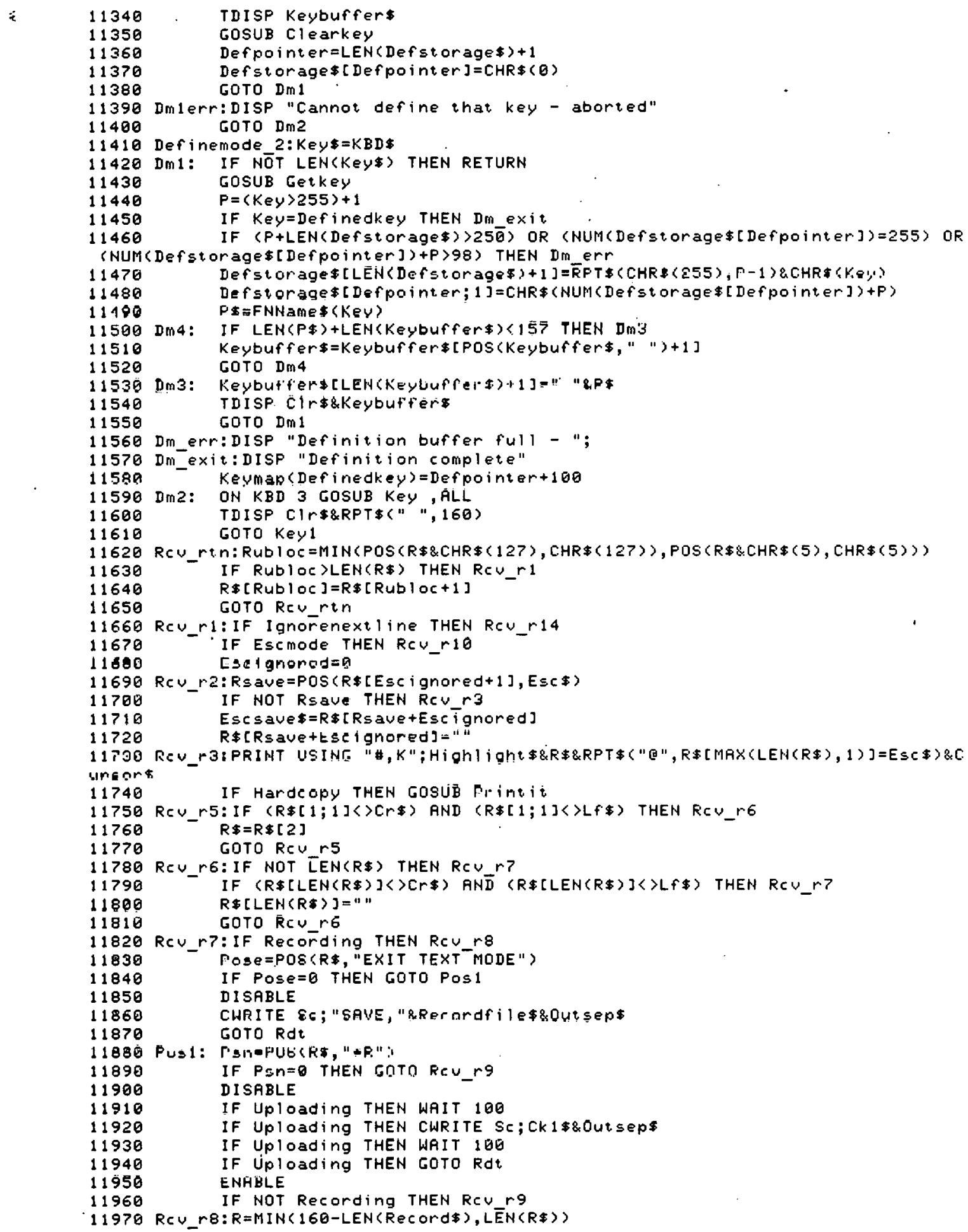




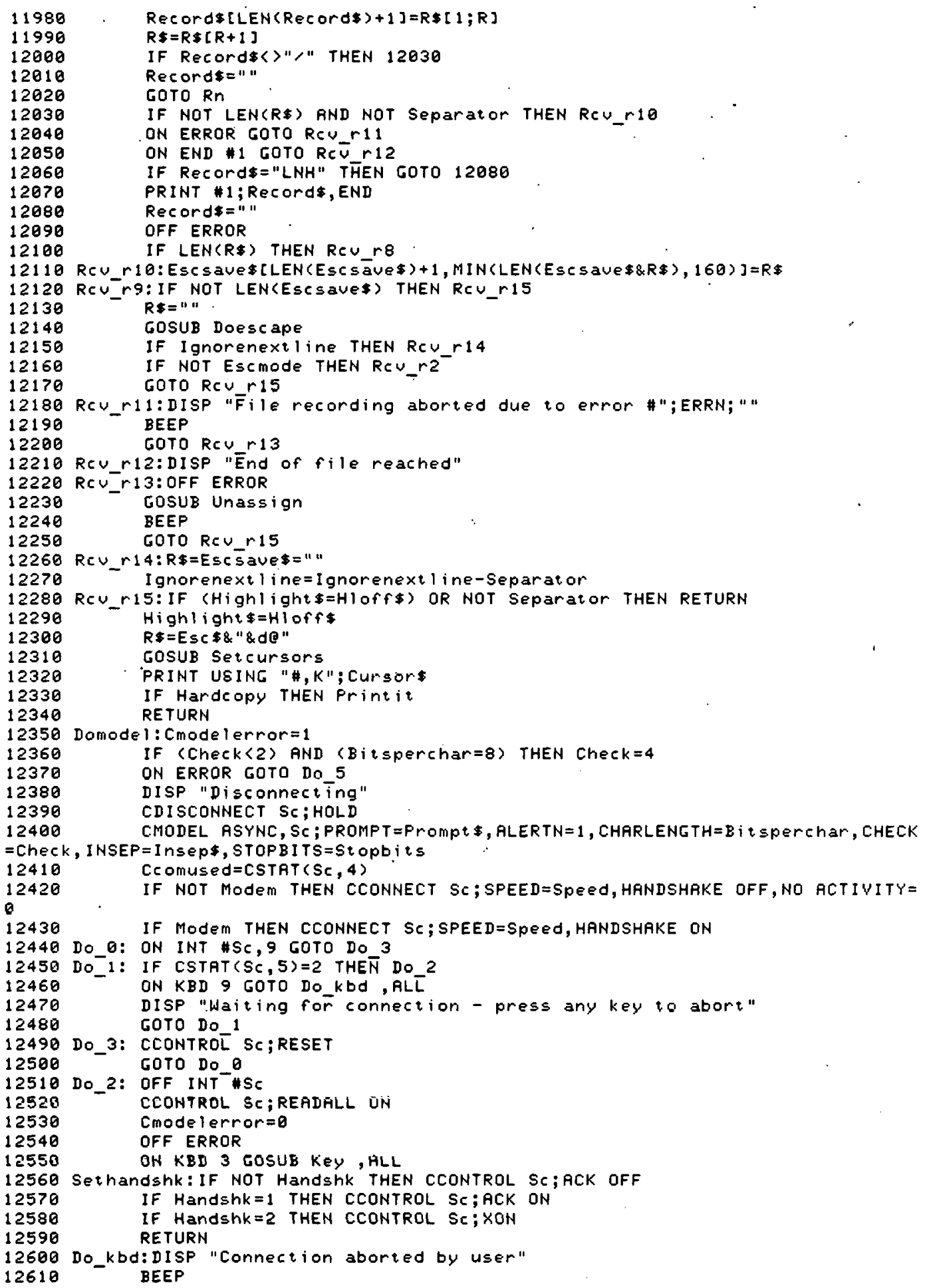




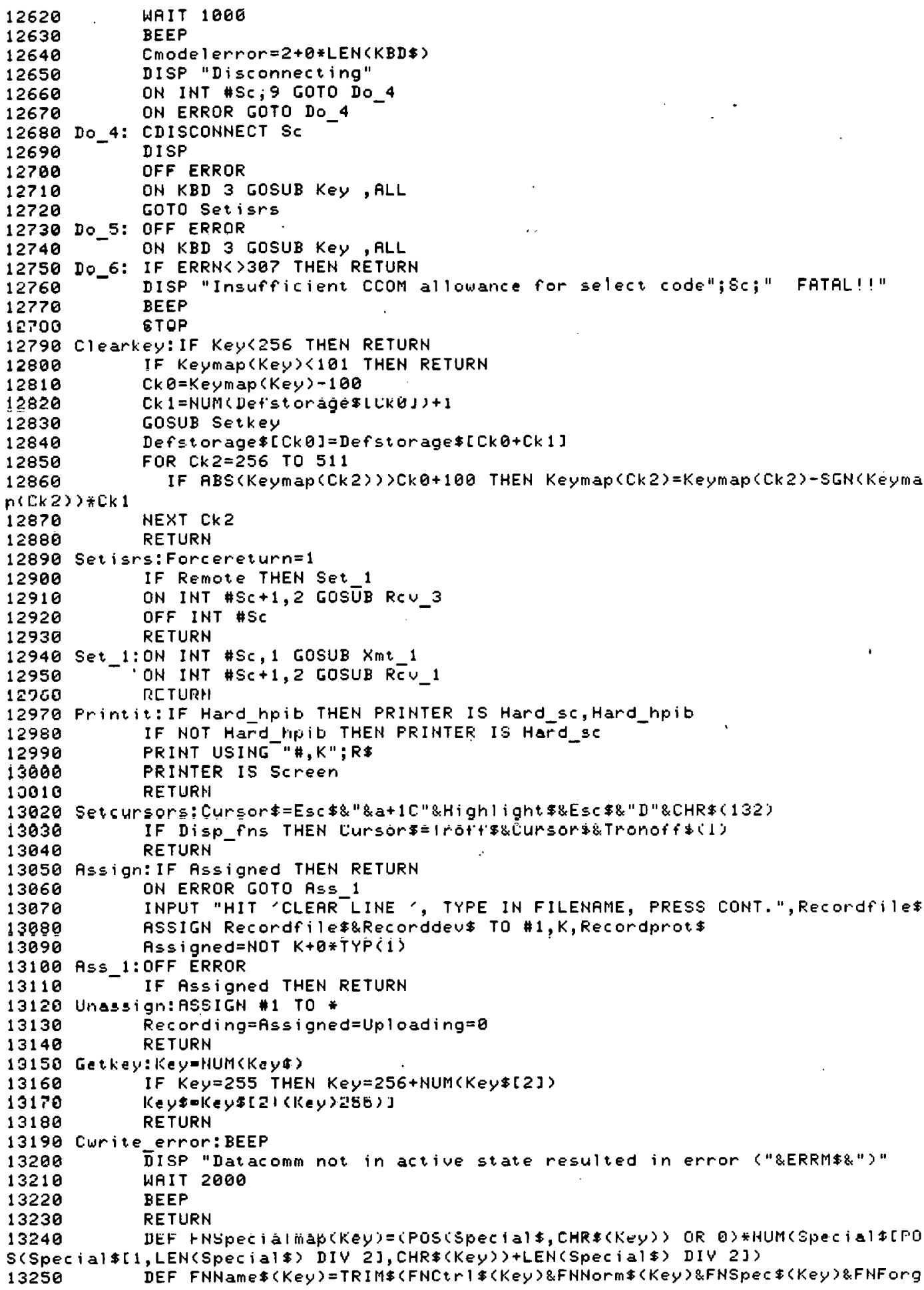




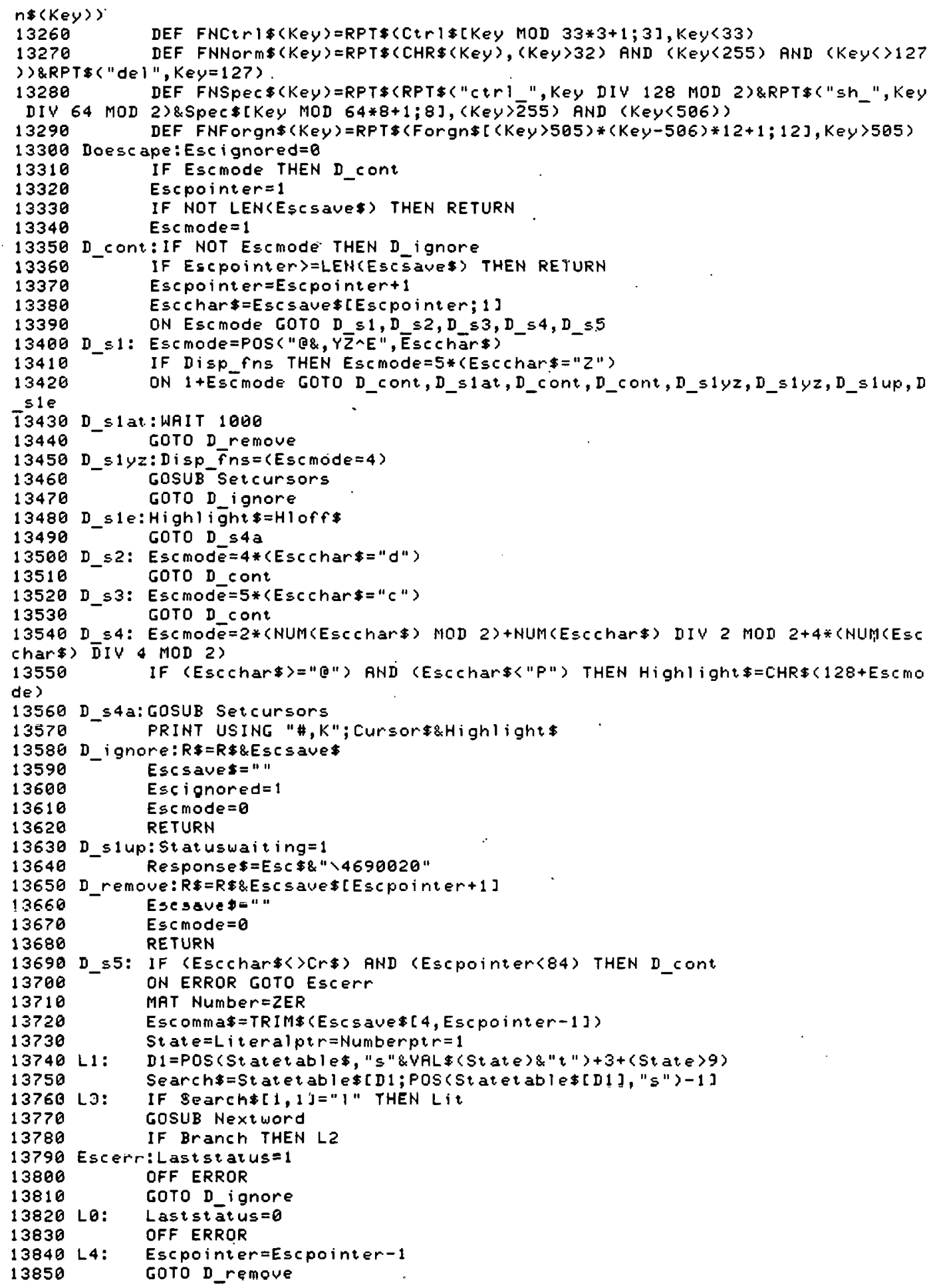




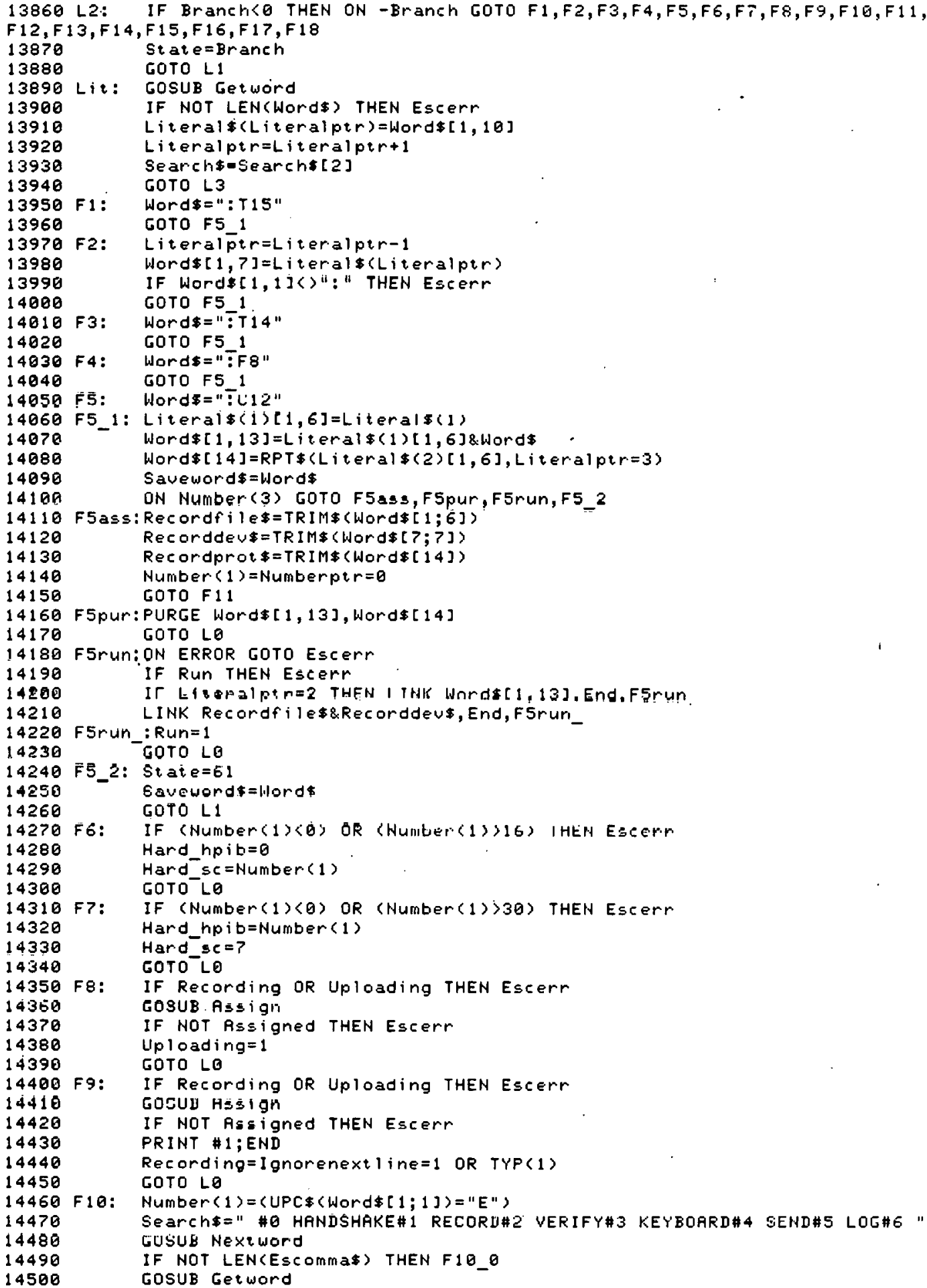




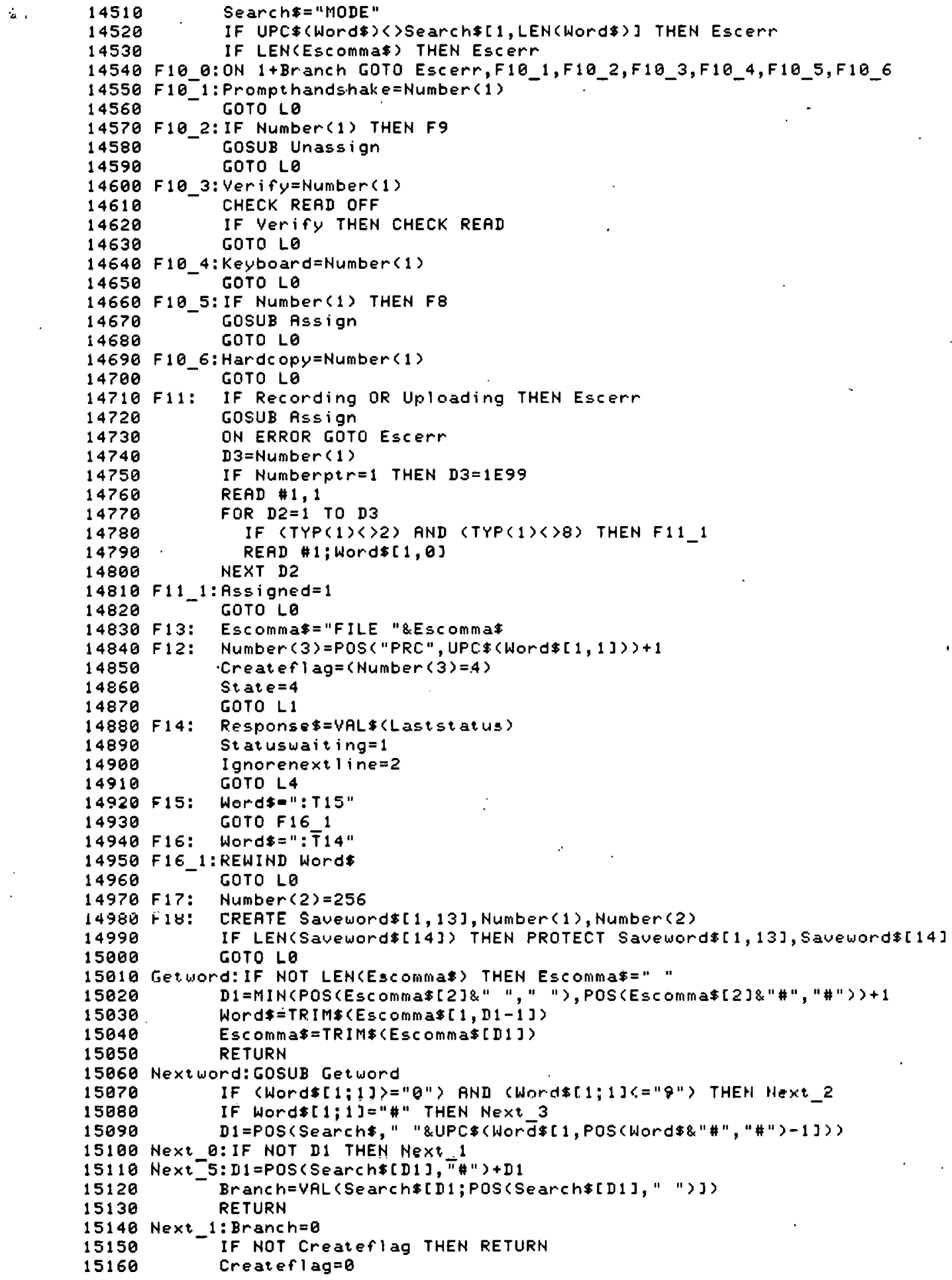




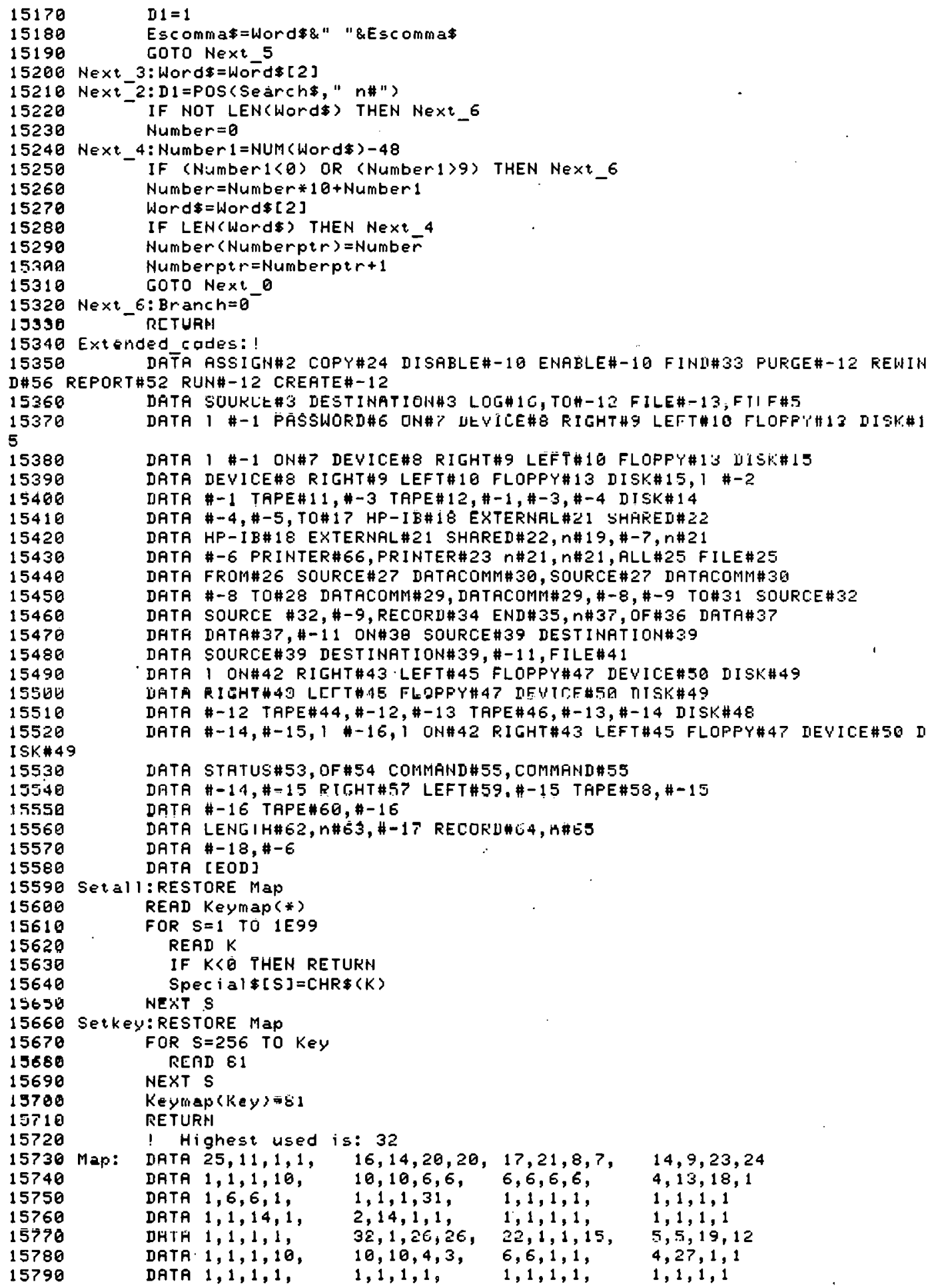




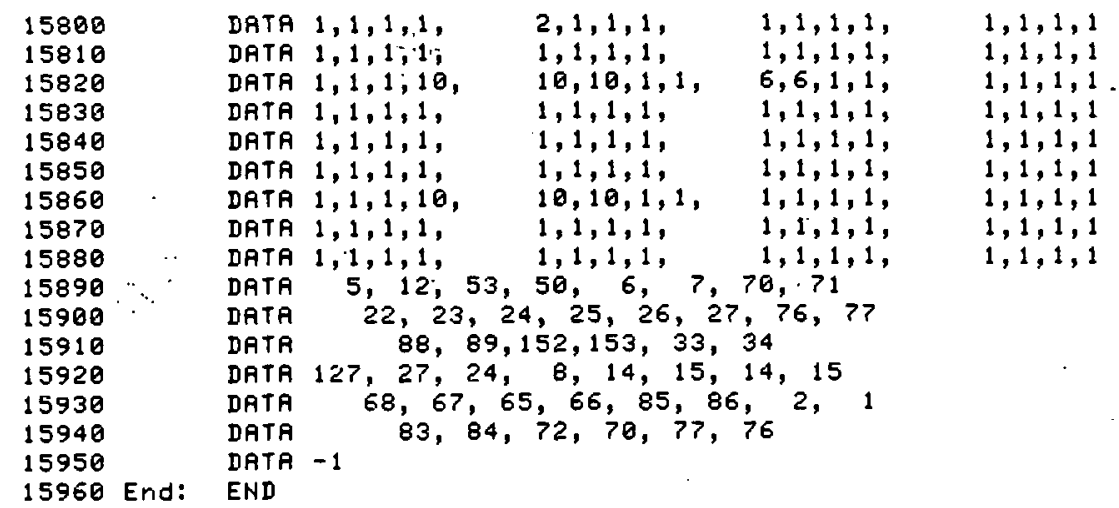


Distribution:

2513 S. A. Sheffield

5130 G. A. Samara

5131 B. Morosin (10)

5131 D. D. Bloomquist (10)

5131 D. L. Allensworth

$5131 \mathrm{~J}$. R. Browning

5131 M. R. Brown

5131 B. W. Dodson

5131 D. W. Dugan (10)

5131 R. A. Graham

$5131 \cdot R$. E. Setchell

5132 R. C. Hughes

5132 B. E. Hammons (40)

5534 J. R. Asay

5531 L, M. Barker

5534 L. C. Chhabildas

5534 J. L. Wise

3141 L. J. Erickson

3154-3 C. H. Dolin (3)

For: DOE/TIC

8266 E. A. Aas

(Unlimited Release) 


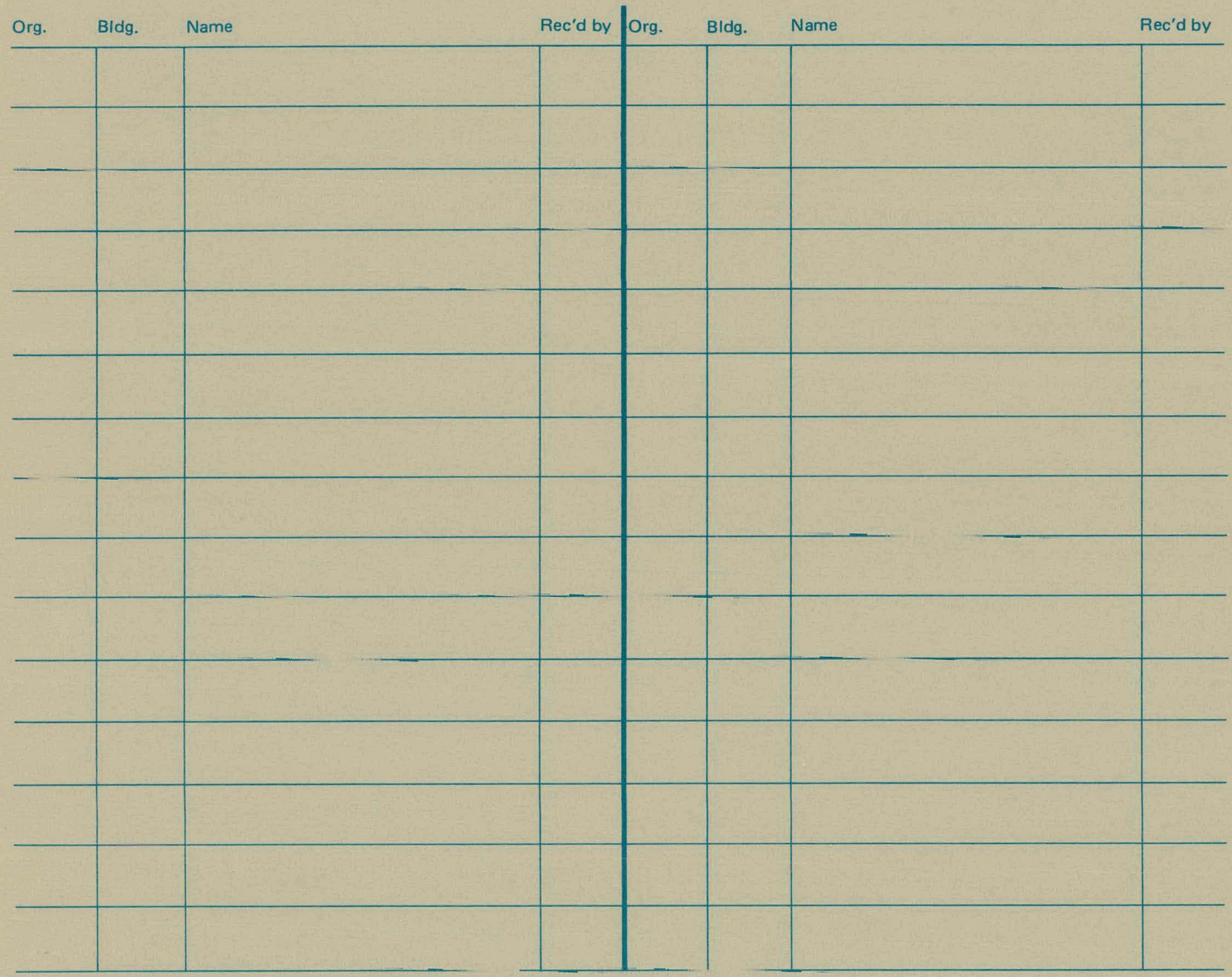

